\title{
Expanding care and support in South India: Scaling up YRG CARE's patient-centered approach
}

YRG CARE

Horizons Program

International HIV/AIDS Alliance

Follow this and additional works at: https://knowledgecommons.popcouncil.org/departments_sbsr-hiv

Part of the Demography, Population, and Ecology Commons, Health Policy Commons, Immune System Diseases Commons, International Public Health Commons, Medicine and Health Commons, Public Health Education and Promotion Commons, and the Virus Diseases Commons How does access to this work benefit you? Let us know!

\section{Recommended Citation}

YRG CARE, Horizons Program, and International HIV/AIDS Alliance. 2004. "Expanding care and support in South India: Scaling up YRG CARE's patient-centered approach," Horizons Final Report. Washington, DC: Population Council. 


\section{Horizons}

\section{Expanding Care and Support in South India: Scaling Up YRG CARE's Patient-Centered Approach}
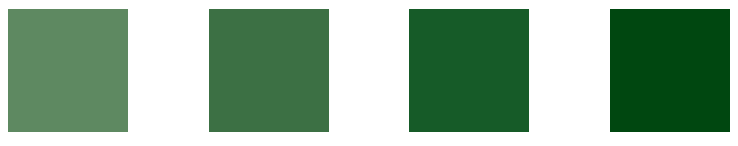

YRG CARE

International HIV/AIDS Alliance Horizons Program 


\section{Expanding Care and Support in South I ndia: Scaling Up YRG CARE's Patient-Centered Approach}

\section{${ }^{\mathrm{H}} \mathrm{X}^{\text {rizons }}$}

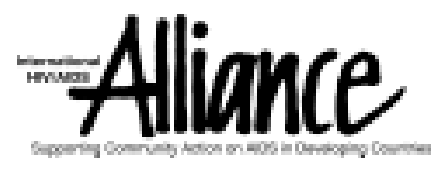


00012-00. The opinions expressed herein are those of the authors and do not necessarily reflect the views of the U.S. Agency for International Development.

Published in January 2004.

For more information, contact:

Population Council/Horizons

\author{
YRG CARE \\ Voluntary Health Services \\ Taramani \\ Chennai, India 600113 \\ Tel: 914422542929 \\ Fax: 914422542939 \\ Email: info@yrgcare.org \\ http://www.yrgcare.org
}

Washington DC 20008 USA

Tel: 202-237-9400

Fax: 202-237-8410

http://www.popcouncil.org/horizons

Horizons is implemented by the Population Council in collaboration with the International Center for Research on Women (ICRW), the International HIV/AIDS Alliance, the Program for Appropriate Technology in Health (PATH), Tulane University, Family Health International (FHI), and Johns Hopkins University.

\title{
(P) Population Council
}

The Population Council is an international, nonprofit, nongovernmental institution that seeks to improve the well-being and reproductive health of current and future generations around the world and to help achieve a humane, equitable, and sustainable balance between people and resources. The Council conducts biomedical, social science, and public health research and helps build research capacities in developing countries. Established in 1952, the Council is governed by an international board of trustees. Its New York headquarters supports a global network of regional and country offices.

Copyright @ 2004 The Population Council Inc.

This document may be reproduced in whole or in part without permission of the Population Council provided full source citation is given and the reproduction is not for commercial purposes.

Suggested citation: Horizons Program, YRG CARE, and the International HIV/AIDS Alliance. 2004. "Expanding Care and Support in South India: Scaling Up YRG CARE's Patient-Centered Approach," Horizons Final Report. Washington, D.C.: Population Council. 


\section{Acknowledgments}

This summary report was prepared by Chris Castle based on the following documents:

Individual case studies of the four scale-up projects in Calicut, Chirala, Mysore, and Pondicherry. October 2002. Prepared by S. Swarnalakshmi, Mirriam Raffiq, and Chris Castle, in collaboration with Vaishali Sharma Mahendra, Celine Daly, Benjamin Franklin, Shirley Thomas, S. Sri Priya, A.K. Ganesh, and Suniti Solomon. Available from YRG CARE (Email: info@yrgcare.org).

The YRG CARE Model: An integrated continuum of prevention, and care and support for people living with HIV/AIDS. March 2001. Prepared by Suniti Solomon, Gladston Xavier, A.K. Ganesh, Purnima Madhivanan, N. Kumarasamy, Benjamin Franklin, and Chris Castle. (www.popcouncil.org/pdfs/horizons/yrgcrbsmdl.pdf)

Scaling Up Care and Support: Horizons/YRG CARE Study, workshop report. December 2002. Written by S. Swarnalakshmi and Chris Castle. Available from YRG CARE (Email: info@yrgcare.org).

"Sharing lessons learned: Scaling-up care and support for PLHA requires vision, flexibility." Written by Margaret Dadian. Horizons Report, December 2002, pages 10-11. www.popcouncil.org/horizons/newsletter/horizons(5)_4.html

"Strengthening HIV/AIDS care and support also improves prevention," oral presentation, XIV International AIDS Conference, July 2002. Chris Castle, Suniti Solomon, S. Swarnalakshmi, Shirley Thomas, S. Sri Priya, and Celine Costello-Daly.

“ 'Teach a man to fish, you feed him for his lifetime': an approach for scaling up HIV/AIDS care and support," poster presentation, XIV International AIDS Conference, July 2002. Shirley Thomas, N. Kumarasamy, Chris Castle, A.K. Ganesh, Paul Janssen, Celine Costello Daly, Benjamin Franklin, Suniti Solomon.

We gratefully acknowledge the scale-up partners and the clients of services in Calicut, Chirala, Mysore, and Pondicherry, as well as the research and clinical staff of YRG CARE for their assistance in the collection and interpretation of data.

We would also like to thank other individuals who were indispensable to the completion of the study and the review of this report: Michael Bailey, Anne Scott, Isabelle de Zoysa, Divya Bajpai, Sujit Ghosh, Paul Janssen, Jocelyn DeJong, Gail Goodridge, and the members of the project's Technical Advisory Group. 



\section{Table of Contents}

Acronyms and Abbreviations

Executive Summary 1

Introduction $\quad 5$

Background $\quad 5$

The YRG CARE model 5

Scaling up $\quad 6$

$\begin{array}{ll}\text { Strategy for scaling up } & 7\end{array}$

Research Objectives and Methods 9

$\begin{array}{ll}\text { Limitations of the study } & 10\end{array}$

$\begin{array}{ll}\text { Study sites } & 10\end{array}$

Findings by Site $\quad 13$

$\begin{array}{ll}\text { Calicut } & 13\end{array}$

$\begin{array}{ll}\text { Chirala } & 16\end{array}$

Mysore $\quad 20$

$\begin{array}{ll}\text { Pondicherry } & 23\end{array}$

$\begin{array}{ll}\text { Financial Analysis } & 27\end{array}$

Key Findings Across Sites $\quad 32$

$\begin{array}{ll}\text { Discussion and Conclusions } & 39\end{array}$

$\begin{array}{ll}\text { References } & 41\end{array}$

$\begin{array}{ll}\text { Appendix } & 42\end{array}$ 


\section{Acronyms and Abbreviations}

$\begin{array}{ll}\text { AIDS } & \text { Acquired immune deficiency syndrome } \\ \text { ART } & \text { Antiretroviral therapy } \\ \text { CBO } & \text { Community-based organization } \\ \text { CME } & \text { Continuing medical education } \\ \text { ELISA } & \text { Enzyme-Linked ImmunoSorbent Assay } \\ \text { HIV } & \text { Human immunodeficiency virus } \\ \text { M\&A } & \text { Medical and Allied, Incorporated } \\ \text { MoU } & \text { Memorandum of understanding } \\ \text { NACO } & \text { National AIDS Control Organization } \\ \text { NGO } & \text { Nongovernmental organization } \\ \text { OI } & \text { Opportunistic infection } \\ \text { PLHA } & \text { People living with HIV and AIDS } \\ \text { PMTCT } & \text { Prevention of mother-to-child transmission } \\ \text { Rs. } & \text { Indian rupees } \\ \text { SFDRT } & \text { Society for Development Research and Training } \\ \text { SHADOWS } & \text { Solomon Health And Development of the Weaker Societies } \\ \text { STD } & \text { Sexually transmitted disease } \\ \text { TB } & \text { Tuberculosis } \\ \text { VCT } & \text { Voluntary counseling and testing } \\ \text { YRG CARE } & \text { Y. R. Gaitonde Center for AIDS Research and Education }\end{array}$




\section{Executive Summary}

The number of new HIV infections in India is rapidly increasing and the health care system is already seeing a substantial increase in the demand for services. There are reports that people living with HIV and AIDS (PLHA) in India face severe discrimination and stigmatization and have limited access to appropriate care for HIV-related health problems. To prepare for increasing demands on health care resources due to HIV-related disease and to ensure that patients seeking care do not encounter stigma and discrimination, this study examines the experiences of Y.R. Gaitonde Centre for AIDS Research and Education (YRG CARE), a Chennai-based NGO, which provides an integrated continuum of prevention, care, and support services for PLHA in a country with an emerging HIV/AIDS epidemic.

In this report, the authors examine the process of scaling up YRG CARE's patient-centered approach and how this had led to the enhanced provision of care and support services at four selected sites in South India. The research employed a comparative case study approach using data collected at the four scale-up sites. Specifically, data were collected through situation assessments, process documentation, and in-depth interviews with scale-up partner staff and others at baseline (January 2000) and two years later (January 2002). At the end of the project, the scale-up partners participated in a data interpretation workshop, which resulted in the synthesis of key findings across the project sites.

The impetus for scaling up came from YRG CARE itself, realizing that the numbers of clients seeking their services would continue to grow rapidly, and that many travel long distances to reach YRG CARE. Discussions and strategic planning with the International HIV/AIDS Alliance resulted in the formulation of a plan to scale up services, and Horizons was invited to collaborate on research to study the process followed and resources required to introduce expanded care and support services in the other sites. The strategy that guided the scale-up process was concept replication. This means that the needs and opportunities of the local context, including existing and potential HIV/AIDS service providers determine how the underlying principles of integrated, patient-centered services are applied.

\section{Key Findings}

\section{Selecting appropriate partners with shared vision and commitment is essential.}

The scale-up strategy of concept replication relies on trust and the mutual sharing of experiences and expertise among the scale-up partners and YRG CARE. At an end-of-project workshop, all participants agreed that selecting like-minded and compatible partners with shared objectives is very important. 


\section{H}

\section{Building skills in the provision of care and support works best when careful attention is paid to provider needs and when the capacity building program is flexible.}

The study underscores the importance of starting with a solid assessment of care and support needs among service providers, working closely with them to identify a training program to fill gaps and respond to priority needs and interests. There was a strong preference for on-site training wherever possible to ground the training in day-to-day realities, and to enable more local staff and volunteers to participate. Capacity building therefore needs to be flexible and accommodate mid-term corrections if necessary. Finding ways to strengthen community participation and have their perspective count is very important. When possible, capacity- building efforts should be extended to government service providers and others as a way of improving skills and strengthening networking and collaboration.

\section{As collaboration and networking intensified, referrals grew and care options increased.}

A key strategy for all the scale-up partners was to strengthen linkages with other care providers and encourage referrals. An increase in referrals was observed as networking and collaboration intensified through efforts such as working with providers to offer continuing medical education. A manager at one scale-up partner commented positively on this link:

"All the local NGOs are referring people to us. We in turn use our network of hospital, labs and clinics for their proper care."

\section{Documentation, monitoring, and reporting were challenges for all the scale-up partners.}

Participants in the study described documentation, monitoring, and reporting as a gradual process of learning and improving, and felt that there had been steady progress throughout the scaling-up period. Nonetheless, documentation was a weakness widely acknowledged by participants. Several reasons were identified as hindering good documentation, including fear of criticism, lack of human resources and skills to monitor and document activities, lack of clarity about the purpose and value of documentation and reporting, and weak organizational commitment for documentation efforts.

\section{Provider attitudes shifted from an emphasis on clinical aspects to valuing patient-centered care and support.}

As is evident in the case studies and from discussions during the workshop, all participants reported a shift from an emphasis on the clinical aspects of HIV at the beginning of the scale up, to a much greater emphasis on counseling and other forms of psychosocial support to PLHA, their families, and communities. Study data underscored the importance of counseling and support within the continuum of care, with clients placing particular value on this. One manager of a scaleup partner commented: 
"The management of HIV/AIDS is not merely a clinical management...the entire system should be linked and followed up, failing this [care and support] will not be complete."

\section{Increased availability of care was associated with higher demand for prevention and care services.}

Through the provision of expanded care and support, partners established more contact with affected communities, resulting in more targeted prevention services with such key populations as sex workers, men who have sex with men, and PLHA.

\section{Stigmatization of PLHA and their families required significant attention at all the sites.}

Expanded involvement in care and support required service providers to address stigma and discrimination experienced by PLHA. The scale-up partners intensified educational and awarenessraising activities about the rights of PLHA as well as protests against providers who refused to treat PLHA or who treated them poorly. The study found that continuing medical education and various training efforts with other providers were useful ways to improve the treatment of PLHA and address stigma and discrimination.

\section{Much can be accomplished through locally led capacity building.}

This study showed that care and support can be successfully expanded without reliance on large amounts of external funding for outside trainers and seed grants. The small seed grants reached the scale-up partners late, yet many services had improved and expanded prior to the arrival of these grants. All partners were adept at mobilizing local cash and in-kind contributions. Community mobilization yielded volunteer labor and other valuable forms of support. All study participants acknowledged the value and importance of the capacity building program led by YRG CARE with technical support from the International HIV/AIDS Alliance, and cited this as the foundation for successfully scaling up care and support.

\section{Conclusions and Building on the Research}

Concept replication as a strategy for scaling up can result in strengthened and expanded care and support for PLHA and their families. For this approach to work well, it is essential for partners to have a shared vision, goal, and set of objectives.

Over the course of the scaling up, providers came to appreciate patient-centered care and nonclinic-based forms of care and support, including a wide range of counseling and psychosocial support. As the scale-up partners increasingly focused on services in these areas, local government and private hospitals could see the increasing value of referral, and the continuum of care began to 


\section{${ }^{H} \boldsymbol{X}^{\text {rizons }}$}

take shape. Networking and collaboration among providers at all sites were essential parts of the strategy.

The scale-up partners and YRG CARE believe that their pioneering efforts are essential in preparing for the expected larger numbers of PLHA seeking care and support services. With the increasing availability of less expensive antiretroviral drugs, many more people are expected to seek HIV testing, resulting in ever-greater numbers of people who know their HIV status and will thus need care and support.

Future efforts are likely to explore strategies for further improving the quality of service provision and for expanding access to antiretroviral therapy, as well as ways in which PLHA who are taking new medications can be supported to achieve a high level of adherence to those drugs. 


\section{Introduction}

\section{Background}

The number of new HIV infections in India is rapidly increasing. Although the estimated overall HIV prevalence is 0.8 percent of the adult population, the country's immense population means that even relatively low HIV prevalence estimates translate into large numbers of PLHA. There are currently 3.97 million PLHA in India, making India the country with the second-largest number of PLHA in the world. As increasing numbers of HIV-infected people become ill, the demand for care and support services grows.

The health system in India is already seeing a substantial increase in the demand for services, yet there are numerous reports that PLHA face severe discrimination and stigmatization and have very limited access to appropriate care for HIV-related health concerns (Horizons and Impact/FHI 2000). Health care providers in both the private and the public sectors are often reluctant to treat PLHA, and they are unsure about how best to help them. Finally, health planners, policymakers, and program managers in India and other parts of South and Southeast Asia are concerned that there are insufficient resources, experience, and knowledge necessary to provide appropriate and affordable care and support services for PLHA and their families.

Health systems in countries with a more mature HIV/AIDS epidemic have experienced enormous strain, with unprecedented increases in disease yet no additional resources (Gilks et al. 1998). The lesson for countries in Asia and elsewhere with an emerging HIV epidemic is to prepare now for the eventual increase in demand for care and support services. There is an increasing recognition that new strategies and alternatives to cope with this predictable change in the increased burden of disease are a priority.

\section{The YRG CARE Model}

The YRG CARE model has been recognized by India's National AIDS Control Organization (NACO) and others for its innovative and patient-centered approach. YRG CARE's facility at the Voluntary Health Services' hospital complex has developed into a preeminent clinical care and research center for HIV/AIDS in India, and actively shares best practices and current advances in HIV/AIDS care and support with others. It has opened its doors to Indian and international organizations that want to learn more about HIV/AIDS and effective approaches to prevention and care. Through its integrated care and support program, YRG CARE has assisted more than 5,000 PLHA since its inception in 1993, and demand for services is rapidly growing.

YRG CARE has clear priorities for the provision of care to people living with HIV and AIDS in India: to deliver a continuum of care at low cost, to promote early detection of HIV, to focus on the effective treatment of common opportunistic infections, to reduce maternal and fetal transmission wherever possible, and to offer a non-stigmatizing, caring, and confidential environment to all. 


\section{${ }^{H}$ rizons}

YRG CARE also includes primary and secondary prevention within their model of integrated care, including work with schools, young people, and families to prevent HIV transmission; prophylactic treatment to prevent opportunistic infection (OIs); and counseling about nutrition and a healthy lifestyle.

Key features of the YRG CARE model include the following:

- Positive and client-centered attitudes on the part of clinicians and other health care workers, putting the needs of patients and their families at the forefront of service planning and delivery.

- Affordable and accessible services for patients and their families.

- Confidentiality.

- Information sharing about HIV infection, treatments, prevention of HIV infection, and of opportunistic infections.

- Referral for additional services as needed.

YRG CARE offers integrated care and support services for PLHA in Southern India, with the following services provided: individual, couple, and family counseling; voluntary counseling and testing for HIV; and medical services, including outpatient care, day care, inpatient care, and home-based care (for terminally ill, pregnant women, and VIPs). A qualified nutritionist is on hand to provide information about the nutritional needs of PLHA. YRG CARE's hospital at VHS includes a dental clinic for the treatment of HIV-related oral disease. Referrals are made for surgery and invasive procedures.

Staff value their ability to provide holistic and comprehensive support to their clients. Because many clients are routinely turned away from other medical and social service institutions due to suspected HIV status, the comprehensive services, compassionate care, and supportive environment provided by YRG CARE become more meaningful and important.

\section{Scaling Up}

There are few precise definitions of scaling up, but most convey the idea that it is a process of moving beyond the bounds of the original local project to one with a greater impact in numbers of people served, geographic areas covered, and, sometimes, an expanded mandate (FOCUS 1999; DeJong 2003).

Scaling up program size and coverage can be achieved using a variety of strategies.

YRG CARE's strategy for scaling up involves creating partnerships with a variable mix of existing and like-minded NGOs, private sector partners, and government agencies that are committed to developing integrated care and support services through adoption and adaptation of the YRG CARE model.

Central to the success of scaling up is the belief that the lessons of YRG CARE's experience in managing more than 5,000 people with HIV infection over the last decade have to be passed on directly to the clinical staff and counselors involved rather than merely through written guidelines. 
This is because the gap between YRG CARE's patient-centered approach and the tradition of service planning and management in India is too great to be bridged by written guidelines alone. The goal is to change the attitudes of care planners and care providers so that specific clinical and counseling skills can be adopted successfully. This approach is similar to that of behavior change prevention programs that move beyond awareness raising to the adoption, trial, retrial, and eventual maintenance of safer sexual behaviors.

YRG CARE's principal strategy for scaling up is "concept replication." This means that the needs and opportunities of local contexts determine how the underlying principles of integrated, patientcentered services are applied. The framework that emerges from this depends on the involvement of YRG CARE clinicians and educators at each stage of scale up, with new organizations seeking to establish their own continuum of prevention and care services. Once the attitude shift has been adopted and consolidated through experience, the scale-up partner will have the potential to act as focal points for further scale up. They in turn will need further technical support and skills building to undertake that mobilization and capacity building role. This latter aspect of scale up is beyond the scope of this research, yet some tentative developments in this direction have already been observed.

\section{Strategy for Scaling Up}

The scaling-up program followed a strategic plan that included:

- Setting criteria for selection of potential partner organizations and groups.

- Initial orientation and participatory organizational needs review.

- Strategic planning and technical support to assimilate and consolidate new attitudes, approaches, skills, and systems.

- Launch, piloting, revision, and establishment of new service elements.

- Monitoring, evaluation, and review.

Small seed grants of less than US $\$ 3,750$ each were made available to the scale-up partners to enable them to get started with expanded delivery of services while their capacity to mobilize local resources was being developed. This funding was provided through the Alliance and YRG CARE, as part of a grant from the John D. and Catherine T. MacArthur Foundation.

The basis for the scaling-up initiative was a capacity building program for the partners that included training and activities in the following areas:

- Organizational development.

- Technical skills building in clinical management and service delivery.

- Continuing medical education (CME).

- Site visits and on-site training/technical support.

- Centralized training for all partners.

- Exposure/exchange visits. 


\section{${ }^{H} \boldsymbol{X}^{\text {rizons }}$}

- Ongoing support, regular communication, and visits.

Appendix 1 contains a table indicating the topics, duration, and participants of various training programs during the scale up period 2000-2001. This is followed by a second table indicating the CME courses offered. 


\section{Research Objectives and Methods}

This research employed a comparative case study approach using data collected at four scale-up sites, drawing on both observed and reported changes.

The research was implemented by a local research team based within YRG CARE. The local team consisted of a coordinator, three research associates working on costing, documentation and data collection, a data entry specialist and a secretary. Some of the qualitative data were collected by an outside group that eventually became part of YRG CARE's in-house research department. The Principle Investigator for the study was Dr. Suniti Solomon, also the director of YRG CARE. Horizons provided support to the local research team for training, technical support, instrument development, quality control, data management and analysis. Horizons, YRG CARE, and the scaleup partners all collaborated on data interpretation.

The objectives of the study were to:

- Examine the process followed and resources required to introduce expanded services in other settings in South India.

- Determine how successfully the strategy of concept replication has been operationalized in different socio-cultural and service delivery settings.

- Synthesize and disseminate lessons learned from the experiences of the scale-up partners in developing and expanding care and support services for PLHA.

To accomplish these objectives, the following research activities were undertaken:

- Documentation of the YRG CARE base model to describe the program's conceptual and operational models and procedures and systems for maintaining standards of care (see Soloman et al. 2001).

- Researchers collected data at baseline (round 1) and two years later (round 2) through situation assessments, process documentation, and in-depth interviews (IDIs) with scale-up partner staff $(n=24)$ and with other providers who intereacted with the scale up partners $(n=5$; one per site and two from one site). In addition, interviews were conducted with 39 male and female clients at end of project only (approximately five men and five women per site) to learn more about their perspectives of services.

- Program documentation was reviewed throughout the project to examine levels of service use, organizational developments and changes, and ongoing partner experiences with the scale-up process.

- Financial analysis was conducted based on the estimated costs of newly acquired resources (labor, supplies, and materials) to support the scaling-up process, using accounting data obtained from the scale-up partners.

- The data listed above were compiled into four individual case study reports that were reviewed by the scale-up partners at a data interpretation workshop. These reports combined with the input from partners provided the basis for the cross-cutting analysis in this report. 


\section{Limitations of the Study}

Our study contains a number of limitations, perhaps the most significant of which is the lack of comparison with other approaches for scaling up. However, given the newness of HIV/AIDS care and support activities at the time the study was undertaken in India, comparative options were very limited. Instead, the natural variation among the scale-up sites and configuration of scale-up partners at each site does provide some opportunity for contrasting experiences.

Weak documentation skills among the scale-up partners hindered the detailed collection of service statistics, including sex-disaggregated data, throughout the scaling-up process that had been envisioned in the proposal. Efforts were made to streamline and simplify the monitoring and reporting systems, but the quality of these data was sometimes disappointing and resulted in gaps in information. Since the scale-up sites were by design scattered throughout South India, it was not possible to visit the partners as frequently as might have been ideal to support and improve the monitoring and documentation effort.

Since the AIDS epidemic is relatively new in India, the numbers of people who know their HIV status and might seek care and support services are low. This meant there was a limited pool from which to sample clients of the new or expanded care and support services. Instead, the study emphasized the attitudes and practices of service providers and the scaling-up process itself.

Finally, as part of an effort to minimize disruption at the scale-up sites and to maximize coordination between support for the interventions and the implementation of the research, the research team was based within YRG CARE as opposed to operating externally. Thus there was potential for bias, although the research team demonstrated a commitment to transparency and critical analysis, and Horizons researchers-who were able to offer an external perspective-were very active and involved in the implementation, analysis, and interpretation of the study.

\section{Study Sites}

From an initial short list of 12 sites, YRG CARE selected four to participate in the scale-up project. Among the selection criteria was the requirement that potential partner organizations have established abilities to provide counseling or medical services. This is so that YRG CARE staff could help the partner organization build on existing work rather than start from scratch. These established abilities demonstrate commitment to the type of work necessary and make it less likely that the partner organization will drop out of the program. In addition, potential partners must have been working in a priority geographic area, defined as one in which there are already many people who need access to HIV/AIDS prevention, care, and support services. This focuses the resources on areas of greatest current need and is likely to have the greatest impact on reducing long-distance demands on YRG CARE's own services.

The four sites selected for participation in the scaling-up project were Calicut, Chirala, Mysore, and Pondicherry. Table 1 provides a description of the lead partner or partners in each site. Details 
about each site's characteristics, scale-up process, and accomplishments are contained in the next section on study findings.

\section{Table 1 Scale-up sites and lead partners}

\section{Site and lead partner Partner description}

Calicut, Kerala

Partner: Medical \& Allied

Inc. (M\&A); Shelter

Chirala, Andhra Pradesh

Partner: Solomon Nursing

Home; SHADOWS

Mysore, Karnataka

Partner: Asha Kirana

Pondicherry, Union

Territory

Partners: SFDRT, St. Joseph of Cluny Hospital, and Shanthi Bhavan
A commercial medical supplies and diagnostic business, M\&A established an NGO called Shelter early on to provide a clearer base to implement care and support activities introduced as part of the scalingup process.

Solomon Health and Development of the Weaker Societies (SHADOWS) is a registered NGO located on the grounds of the private family-run hospital, Solomon Nursing Home. Set up in 1989, SHADOWS has been providing health care and community development services in Chirala and the neighboring villages, including community health promotion and local development work with street children, slum dwellers, and sex workers. Since 1993, SHADOWS has been focusing on HIV/AIDS and campaigning for the care and support of PLHA in the area, due to the magnitude of their unmet health care needs.

Asha Kirana is an NGO established to create awareness about HIV/AIDS in various sections of society, both urban and rural, and to de-stigmatize the HIV/AIDS pandemic. The chair of Asha Kirana has had a longstanding connection with YRG CARE, providing pediatric support and expertise to YRG CARE clients through periodic visits.

Three scale-up partners were identified in Pondicherry. The Society for Development, Research and Training (SFDRT) is a community-based NGO that started its HIV/AIDS work on awareness and education, gradually developing care and support services. SFDRT has been conducting various programs since 1996, including but not limited to HIV/AIDS. Their target groups are sex workers, truck drivers, slum dwellers, street children, and bar workers. Cluny Hospital is a 200-bed multi-specialty hospital known for maternity care, with an average of 300 deliveries conducted per month. Shanthi Bhavan is a 10-bed hospice that serves terminally ill PLHA. The Sisters of St Joseph of Cluny run both the Cluny Hospital in Pondicherry and this hospice. Shanthi Bhavan was opened in July 1999. 
${ }^{\text {Hrizons }}$

Map with location of scale-up sites

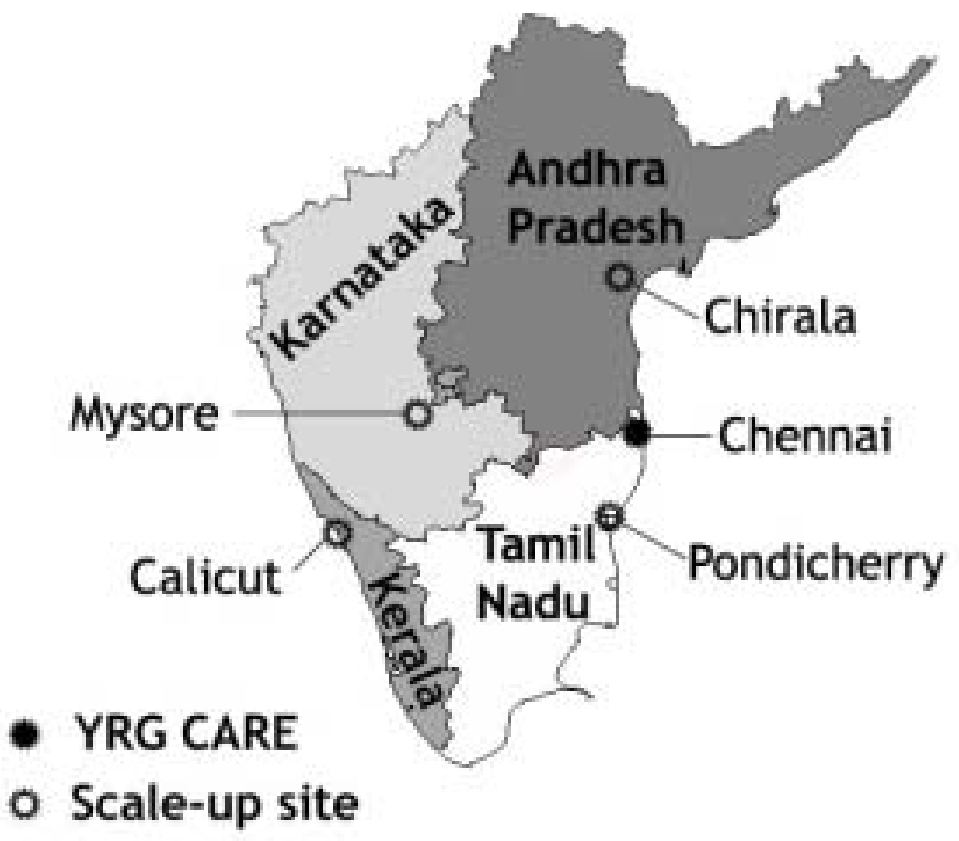




\section{Findings by Site}

\section{Calicut}

Calicut, recently renamed Kozhikode, is the capital of Calicut District, located in the state of Kerala. The city has a population of approximately 1 million, and Calicut district has a population of 2.8 million. NACO surveillance data for 2000 estimate that HIV prevalence was 6.4 percent among STD patients and less than one percent among antenatal clients. The recorded number of people with a clinical diagnosis of AIDS was 864 , although local service providers estimate actual prevalence to be higher.

The initial assessment identified Medical \& Allied Inc. (M \& A), a for-profit diagnostic testing business that provides services to patients from Calicut and the surrounding area, as the scale-up partner. Besides meeting the selection criteria, M\&A's director already had a longstanding relationship with YRG CARE.

At baseline, M\&A offered HIV testing with limited information provided before and after the test, conducted HIV/AIDS awareness raising campaigns in schools, received referrals for diagnostic testing, and referred patients who tested HIV-positive to the Calicut Medical College Hospital for treatment.

\section{Scale-up process}

The limitations of scaling up care and support services from a commercial diagnostic testing facility led M\&A to establish an NGO called Shelter in August 2000. This created a framework from which to meet objectives that were distinct from M\&A's commercial ones. Shelter provided an environment that was more suited to the provision of enhanced counseling, outpatient care, and collaboration and networking with a broad range of other organizations and service providers.

The scale-up team, headed by YRG CARE with support from the Alliance, provided technical support to Shelter in finance, administration, management, fundraising, IEC materials development, HIV clinical management, care and support, and documentation. In addition, the team worked with Shelter and its local networking partners to strengthen their relationship so that it would be mutually beneficial.

At baseline, M\&A wanted to focus on providing clinical services for PLHA. Following exposure to the capacity building activities, there was a clear shift in their strategy toward mobilizing and engaging other community-based organizations (CBOs) to become involved in providing a continuum of care for PLHA, particularly those from populations that are key to the epidemic, such as sex workers and men who have sex with men (MSM). 


\section{${ }^{H} \boldsymbol{X}^{\text {rizons }}$}

Shelter's strategy to network with others rather than provide most services in-house yielded many observable advantages, including better outreach to affected communities, avoidance of duplicative services and competition among providers, and the wider mobilization of key players in Calicut. This approach also led to a clearer understanding of the services available from Shelter among PLHA and other key populations.

"In fact I was not aware that I should link with another CBO or another NGO for such activities, for treating diseases. Now I feel that it was an eye opener in entering into this field, because we had a lot of linking with CBOs, NGOs, and so many other partners with similar interests, and their penetration into their community was far better and their acceptability and credibility, was much better than what I know." Manager, Round 2 IDI

A continuing challenge is to establish patient-centered care and support, particularly since services are provided through a network of partners, and the small size of Shelter's staff makes it difficult to follow up patients. Patient record keeping and documentation has improved at Shelter, a key step toward achieving this goal, but more work remains.

The open-mindedness of Shelter's director and staff to new ways of working was also a critical factor behind the successes in Calicut.

\section{Changes in service provision and utilization}

The sources of income of Shelter are grants and in-kind donations. They do not collect any user fees from clients. The value of financial and in-kind resources received by Shelter to strengthen and expand care and support services during the scale-up period was Rs. 158,000 (seed grant) and Rs. 4,000 for medicines from donations.

As a result of technical support and the income cited above, Shelter has implemented the following services, which greatly complement and expand upon what $\mathrm{M} \& \mathrm{~A}$ had offered:

Voluntary counseling and testing (VCT): Shelter provides VCT per NACO recommended guidelines. M\&A staff now realize that what they provided as part of testing was in fact very limited and did not conform to recognized counseling standards.

Ongoing counseling: This includes nutritional counseling to PLHA and family members, family counseling for family members to provide support and care for PLHA, and follow-up counseling whenever clients and their families visit Shelter. In addition, the counselor also provides telephone counseling to PLHA from the premises of one of the network organizations.

Prevention and awareness raising: Shelter works in collaboration with other CBOs to target interventions to populations that are key to the epidemic, such as sex workers, migrant laborers, men who have sex with men, hotel workers, and prisoners. For example, Shelter's Director provides STD diagnosis and treatment services at a weekly STD clinic run by the Indian Youth Association, which targets men who have sex with men. 
Outpatient care: Shelter provides limited outpatient care. Medical checkups, IVs, and injections are provided as required, and clinic staff also dress wounds, drain abscesses, and check laboratory parameters pertaining to the side effects of antiretroviral therapy (ART). PLHA who can afford to pay for ART (about 30 percent) are provided the drugs through Shelter.

Home care: Home care is not provided directly by Shelter but through its network of CBOs. All the necessary guidelines on home care are provided to the network organizations by the staff of Shelter.

Referrals: M\&A patients are now referred to Shelter for treatment of opportunistic infections, VCT, follow-up counseling, and access to home care. Shelter now has informal agreements with nine specialty doctors-many of whom did not treat PLHA at baseline-who comprise a consortium of consultants to provide specialized medical care to PLHA.

Figure 1 indicates the increase in client utilization of services provided by Shelter's three-person staff plus volunteers for the year 2001, compared to the very minimal care and support service provision offered by M\&A at baseline. It is important to note that M\&A primarily focused on confirmatory HIV testing.

Figure 1 Changes in number of clients per year by service

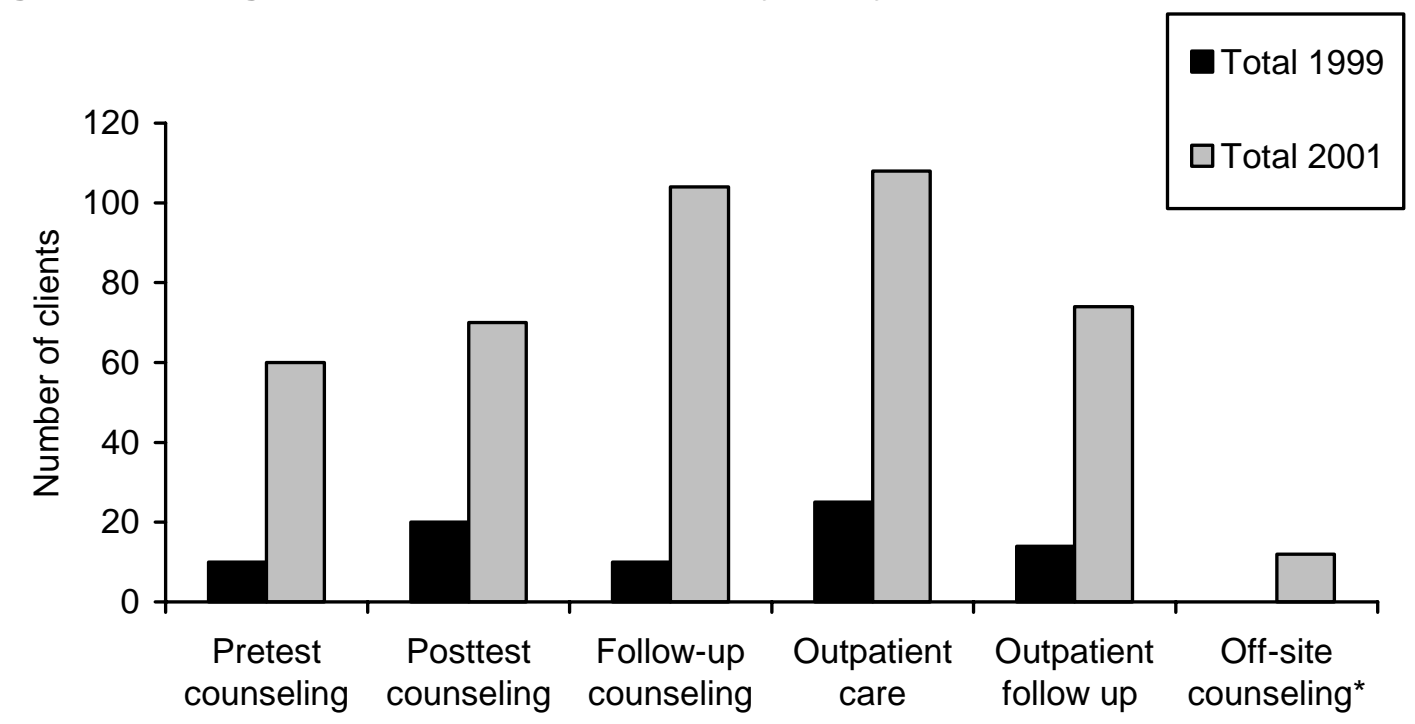

* Off-site counseling was not available at baseline, but was added during the course of the intervention.

Having organized varied capacity building activities for health care providers to enable them to provide quality medical care to PLHA, Shelter has increasingly gained recognition for its work in enhancing technical skills. An indicator of this was their success in being able to mobilize 


\section{Hgrizons}

additional resources from sources other than YRG CARE to conduct two different CME courses in September 2000 (see Appendix 1).

\section{Chirala}

Chirala is a town of about 100,000 people in the Prakasam district of Andhra Pradesh, with the district population reaching 3 million. NACO estimates that Andhra Pradesh is among the states in India with the highest HIV prevalence: just over 2 percent of the adult population, greater than 5 percent among key populations, and 1 percent or more among antenatal women.

Very few care and support services were available in Chirala when the study began in January 2000. YRG CARE selected the NGO SHADOWS (Solomon Health And Development of the Weaker Societies), with its link to the Solomon Nursing Home, as the scale-up partner for the project because it most closely matched the partner selection criteria, and because the Solomon family expressed a strong desire to participate in the scaling-up initiative.

SHADOWS reports that, at baseline, the services they offered included limited counseling to patients and families, general nutritional advice to PLHA, and referrals mainly to YRG CARE and the Christian Medical College in Vellore. Staff were willing to provide clinical care to PLHA, yet training in HIV management was lacking.

\section{Scale-up process}

In many ways, the care and support services scaled up in Chirala most closely resemble the operations of YRG CARE, since the starting point was from a health facility, the Solomon Nursing Home, in conjunction with an NGO, SHADOWS. For this reason, the rationale was strong for a focus on bringing existing clinical and counseling services up to standard, in line with practices established at YRG CARE and according to NACO and internationally recognized guidelines.

Although initially SHADOWS had prioritized its strategy for scaling-up on technology (e.g., obtaining an ELISA reader) and the improvement of medical/clinical services, a clear shift in emphasis can be seen in their attitude. In the end, they cite counseling services as their number one priority.

"Our priority will be counseling, second will be treatment, and third will be testing. In Chirala many testing centers are present, but many do not give counseling. Since the testing is done without counseling, we are coming across many suicide cases. So we want to take that as the first priority. I have seen many CBOs and NGOs in and around Chirala directly giving care and support without starting with counseling. So we networked with them...After discussing we suggested them to take it phase by phase -- first counseling and then you can learn more and go for treatment, which is not available. Third is testing. We chose to put the testing as the third service because testing is not accurate. In Chirala, only 
Tri-dot testing is done and it is not reliable. Due to that there are a lot of false positive cases” Manager, Round 2 IDI

Another noticeable shift was to work on strengthening and better organizing existing services, rather than adding new services. Strengthening infection control and waste disposal procedures, as well as working to improve such administrative tasks as documentation and patient record keeping, took on greater importance. In fact, through greater exposure to the services and practices of YRG CARE, SHADOWS came to realize that many of their services and practices at baseline were below NACO and YRG CARE standards and urgently needed improvement.

Organizational capacity building can be slow, because building skills in these areas can be heavily time-intensive. Midway through the scale-up process, SHADOWS requested support to establish a better management information system and to improve its administrative functions. By the end of project, SHADOWS cited the importance of documentation and monitoring systems as a foundation for improving and expanding their care and support services.

A helpful factor supporting the scaling up was the involvement of an NGO, SHADOWS, and a private commercial medical service (Soloman Nursing Home). The NGO provided the framework through which care and support improvement and expansion could occur. This also meant that existing links with the community could be maximized in support of the scale-up effort. The private nursing home has contributed to sustainability, providing a solid base for the initiative.

The seed grant arrived very late in the scale-up process, yet SHADOWS was able to mobilize local resources and secure other grants to cover costs. While financial inputs are clearly important, the value and effectiveness of capacity building for resource mobilization is clearly a key lesson from this site.

At the end of the scaling-up project period, many components of the YRG CARE model are in place, although more work needs to be done to ensure and maintain the quality of services. Significant progress was achieved on improving infection control, and efforts in this area should continue.

A very important factor behind the success of the scaling up was the dedication, flexibility, and willingness to learn and change on the part of members of the Solomon family, as well as their willingness to take the risk of being branded "AIDS specialists, a potentially negative connotation that could negatively affect their overall practice.

\section{Changes in service provision and utilization}

SHADOWS instituted a cost recovery system to help cover some of the costs of services. Initially, counseling and registration services were offered free of charge. During the year 2000, an informal sliding scale was introduced, with Rs. 100 per patient the maximum charge for counseling.

SHADOWS also began to charge a one-time registration fee of Rs. 500 to Rs. 1000. For inpatients, special rooms are now available for Rs. 50 per day. Tri-dot testing is available for between Rs. 100 


\section{Hgrizons}

and Rs. 250. All local service providers who refer to SHADOWS are informed that a charge is applied according to the patient's ability to pay.

SHADOWS has been successful at mobilizing and retaining volunteers, from ten at baseline to over 70 at end of project. In a resource-constrained setting such as Chirala, volunteer mobilization is an important tool for providing care and support services, especially for the provision of home and community care.

According to other service providers in Chirala, PLHA who would previously have been referred to YRG CARE are now being sent to SHADOWS. However, those with complicated cases are still being referred to YRG CARE.

Service statistics reported by SHADOWS suggest important increases in utilization (Figure 2). However, reporting was not systematic at the beginning of scale-up, and a review of monitoring procedures indicates that baseline service utilization may have been overestimated. Increases in the number of clients seen from October 2001 onwards may be attributed in part to concerted efforts to promote the services of SHADOWS, and intensified outreach within communities.

Figure 2 Number of clients per month accessing HIV/AIDS-related services at SHADOWS (January 2000 to December 2001)

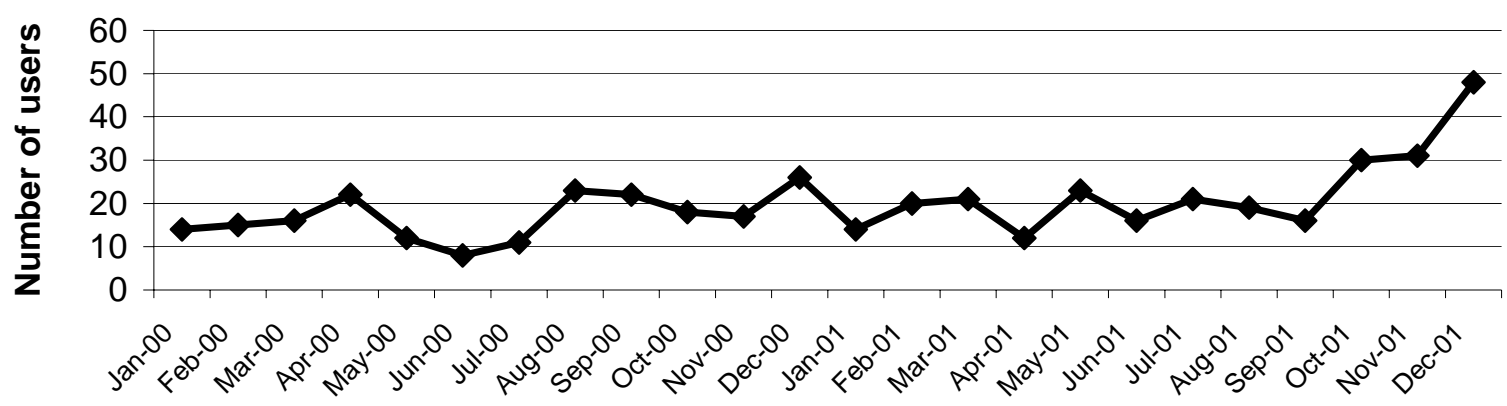

Specific changes in services as a result of the scaling up are as follows:

HIV testing and counseling: SHADOWS now provides VCT as per NACO recommended guidelines. Testing is still limited to tri-dot, however, clients are referred for confirmatory tests (Western blot and ELISA).

Ongoing counseling: SHADOWS counselors and staff report that the quality of family and couple counseling, nutritional counseling, and spiritual counseling has improved as a result of counselor training. Whenever a patient comes for counseling, he or she is now also requested to come periodically (every three months) for follow- up counseling. 
Medical care (outpatient, inpatient and terminal care): Doctors, nurses, and paramedic staff from the Soloman Nursing Home have received training in HIV management. Routine follow-up visits have been initiated and are scheduled every three months. Services have been re-organized with less usage of inpatient services (at baseline, nearly all new PLHA were admitted whether their condition warranted it or not). Infection control procedures have dramatically improved. An additional operating theatre was added through the conversion of an existing room that is solely dedicated to PLHA. As a result, medical services have been expanded to include obstetrical care (including vaginal and cesarean deliveries) and pre- and post- surgical care for PLHA.

Referrals: Referrals to SHADOWS have expanded to include clients in all stages of HIV disease. In the past, the tendency was to see only clients in advanced stages of disease. PLHA are referred by local doctors and from areas outside of Chirala for VCT, medical care, and counseling.

SHADOWS still refer PLHA to CMC Vellore and YRG CARE for specialty care. Clients are also referred to more organizations with whom SHADOWS has begun to network, and they also refer clients to an informal, accessible, and affordable network of local specialists (e.g., for conditions related to dermatology, ophthalmology, etc.).

Home care: SHADOWS will visit clients' homes as part of patient follow-up, mostly for terminal cases. Care policies have been formalized and documented. Nurses and doctors provide home nursing care by means of saline infusions, follow up for cesarean sections, changing bandages, and providing medicines. Volunteers provide home care, such as emotional support, cooking meals, helping around the house, transportation, and conflict resolution/mediation (with neighbors, teachers, and so on). Care and information on home management of PLHA is given to PLHA and their caretakers.

As a result of technical support, volunteer support, and income from user fees, SHADOWS' services have expanded and improved, resulting in greater service utilization (see Figure 3). Unfortunately, a breakdown of the client data by sex is not possible because this information was not carefully monitored. 
Figure 3 Changes in number of clients per year by service

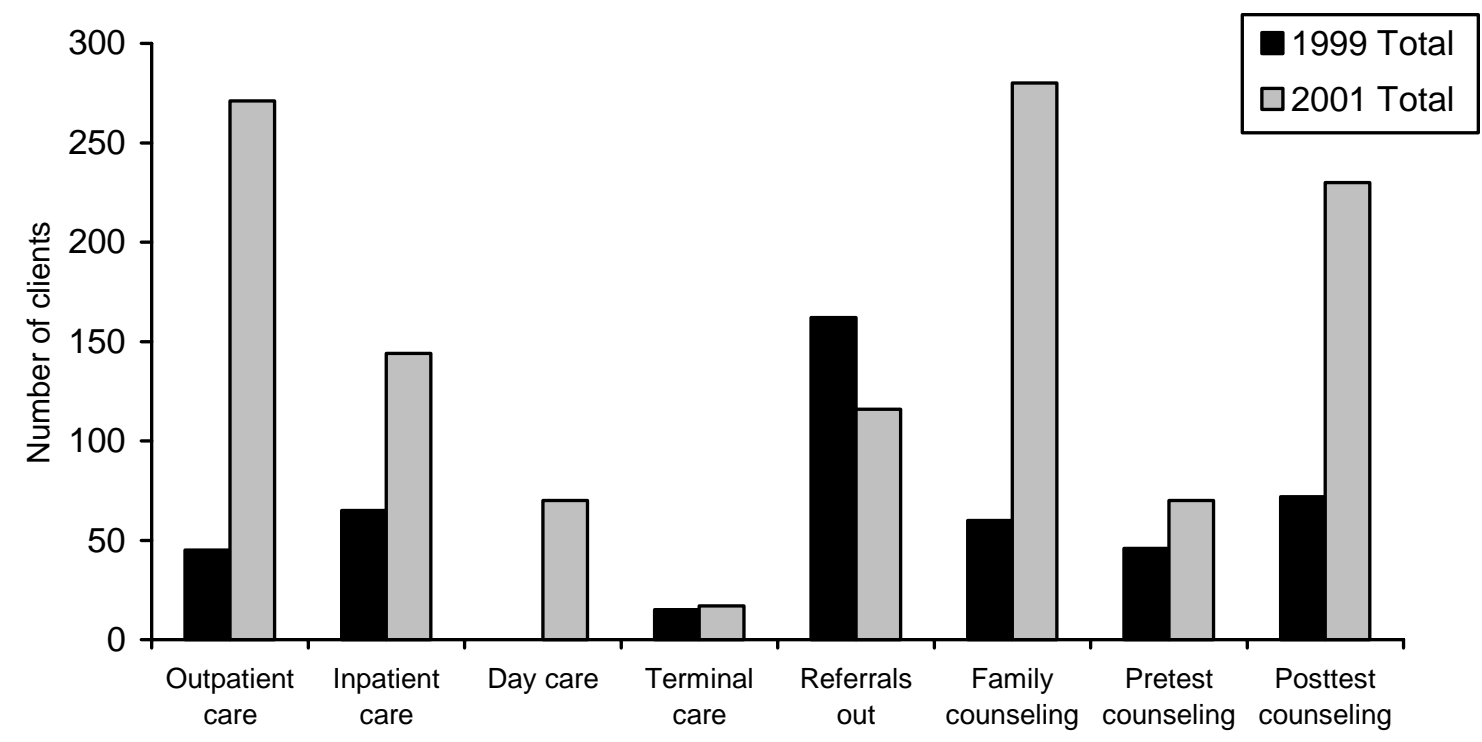

\section{Mysore}

Mysore is a city located in Karnataka, a state in South India with a population of around 53 million people. A recent WHO report states that Karnataka is one of three Indian states with an HIV prevalence of over 2 percent (Ramasundaram et al. 2001). At baseline, a clinical consultant reported estimates that sex workers in the area have an HIV infection rate ranging between 30 and 40 percent, and pregnant mothers have a 1 to 2 percent prevalence rate. Hospitals in Mysore reported at baseline an HIV prevalence of approximately 2 percent of all patients.

The scale-up partner in Mysore is Asha Kirana, a charitable trust that was registered in 1997 to address the need for prevention, care, and support services for PLHA. At baseline, Asha Kirana provided counseling, prevention, outpatient care, a women's clinic, day care, and ELISA testing at its premises. Patients are charged on a sliding scale according to ability to pay. Asha Kirana had assembled a consortium of specialists such as neurologists and obstetricians willing to treat PLHA, demonstrating the potential to facilitate increased cooperation among existing service providers, to strengthen the quality of and access to care, and to develop new services. For these reasons, and because of Asha Kirana's existing and strong relations with local government and private hospitals, they were selected as one of the four scale-up partners for the initiative.

\section{Scale-up process}

The goal of the scale-up project was to ensure that a full continuum of care existed in Mysore for PLHA. The original strategy envisioned that this would be achieved by increasing the local 
capacity of Asha Kirana through skills-building activities and a small seed grant, and networking with existing service providers to avoid the duplication of services. Asha Kirana was more inclined toward adding services themselves rather than supporting other providers to improve and add services. Given the impressive and complementary relationships that Asha Kirana has established with the government TB sanitarium and the private mission hospital, whereby the facilities provide clinical care and Asha Kirana provides counseling, it was hoped that Asha Kirana's aspirations to develop care and support services for PLHA itself would not result in a duplication of services.

Impressive improvements in the counseling services provided by Asha Kirana have resulted in praise from other service providers and strong appreciation by clients. Asha Kirana credits training from YRG CARE as a major factor in strengthening their counseling. The counselors themselves report much more confidence in the counseling they provide and in their capacity to now raise such sensitive but vital issues as sexuality and risk assessment.

"One major thing acquired is the sharpening of counseling skills, but we never had any budget to help [the counselors]. Talking to the patients in a different manner has satisfied them and more and more patients have started coming, especially after the family counseling has started." Manager, Round 2 IDI

The results of Asha Kirana's efforts to strengthen and expand medical services has been mixed. On the positive side, outpatient services are now offered on its premises, in particular to treat opportunistic infections. Establishment of inpatient services has been more problematic. With a grant from NACO through the state AIDS cell, they established a ten-bed inpatient and day care facility at Ravi Nursing Home; however, this initiative ended after several months due to management and other differences between Asha Kirana and Ravi Nursing Home.

Of particular significance is the dedication and commitment of the trustees of Asha Kirana, identified as a major strength of the organization, and a critical factor behind the success of its achievements. Individual trustees who volunteer their time to provide clinical services, and others who mobilize resources, have made essential contributions to the scaling-up effort.

\section{Changes in service provision and utilization}

Asha Kirana added one counselor, one scale-up coordinator, one doctor, one office administrator, three health care workers, and one part-time driver. The source of income for the doctor, office administrator, and health care workers is NACO. During the scale-up period, Asha Kirana wrote proposals to other organizations and succeeded in securing Rs. 3,533,601. These were raised from NACO and Rotary International. Voluntary contributions from Asha Kirana trustees continued, and user fees from the ambulance and laboratory services also increased revenue.

In terms of inputs that went into supporting the scale up in Mysore, Asha Kirana participated in numerous capacity building activities provided by YRG CARE, including central trainings, site visits, exchange visits, and continuing medical education events. 


\section{H}

The technical support and income noted above have resulted in the following:

Prevention: Asha Kirana's work in prevention not only continues but also appears to be intensifying, with more targeted programs and greater coverage. Given the pervasive stigma and discrimination against PLHA in Mysore, Asha Kirana prioritize their prevention and education efforts accordingly, and view this as the most effective way that they can address stigma and discrimination. The number of people reached by awareness activities is reported to have increased, although Asha Kirana has not provided specific numbers.

VCT: Asha Kirana report that the number of walk-in clients for VCT has increased; however, they are unable to provide statistics to support this. Advertising is done with posters and commercials on local cable television. As a result of awareness programs, networking, and increased referrals, Asha Kirana report that there are more people coming for testing. VCT services are also now offered to prison inmates as part of counseling at the Central Prison in Mysore, yet the uptake of this service is reportedly low.

HIV testing: Some ELISA tests are done free, sponsored by RPG Cables, a locally based business. Lab technicians have been trained at YRG CARE. People are reported to come for HIV testing daily. Other lab services have been added, including urine tests and VDRL slide tests.

Counseling: Counseling is provided free of cost, and Asha Kirana suggests to patients that they come every month for clinical follow up and whenever they have a problem. Asha Kirana reports that 70 to 80 percent of patients return for follow up counseling. Asha Kirana staff continue to visit the Central Prison, Mysore, every Friday of the month, yet now they provide counseling to the prison inmates, going beyond the awareness-raising activities noted at baseline. The visits include speaking to the inmates about various issues, including their social problems, and also awareness about HIV/AIDS and precautions to prevent infection.

Outpatient care: Outpatient clinical care continues to be provided on the premises of Asha Kirana. There are now four doctors (a gynecologist, two medical officers, and one pediatrician) and two full-time counselors available from 9 a.m. to 4 p.m. to serve outpatients. They provide services such as injections, wound dressings, diagnoses, and referrals. Asha Kirana reported that the number of clients receiving outpatient care increased from 273 in 1999 to 1758 in 2001.

Referrals: Asha Kirana refers patients to Holdsworth Mission Hospital and PK TB Sanitarium as appropriate. Asha Kirana refers terminally ill patients to Vimala Terminal Care Center, which is run by the Catholic Mission. Referrals to Asha Kirana have reportedly increased, but they have not provided specific statistics to support this.

Funeral services: Asha Kirana has decided that it will bear the expense of funerals for unclaimed bodies of HIV patients where appropriate. It also helps by sending its ambulance and bearing the burial/cremation costs of unclaimed bodies.

Networking: Asha Kirana is now part of a network of NGOs and a network of doctors in the area, the latter composed of a consortium of consultants comprising 23 doctors. Networking has also 
developed among HIV-positive people, for which support group meetings are held every month at Asha Kirana.

Family counseling: At baseline, counseling was given only to individuals. Family counseling was not given because there had not been a perceived need for this service. Now the counselors have gained more experience in family counseling, and more family members come for this service. Often at least two to three members of a single family come for counseling. However, family counseling is done only when the family members are willing to come, and is thus not done regularly. PLHA are encouraged to involve family or spouses.

Inpatient care: Asha Kirana had established a ten-bed facility available at Ravi Nursing Home for inpatients, with funding from NACO. Doctors and one counselor from Asha Kirana visited Ravi Nursing Home daily to provide this care. Management and other differences between Asha Kirana and Ravi Nursing Home resulted in the cessation of the arrangement after several months, and a return of the grant to NACO.

\section{Pondicherry}

Pondicherry is a Union Territory in South India with a population of 970,000. The town of Pondicherry has 220,000 people. Pondicherry is a former French colony and has a large tourism industry and transitory population. Adult HIV prevalence is among the highest in India, estimated at about 3.5 percent (USAID/Society For Development Research and Training 2001). A 1998 WHO and UNAIDS report cites HIV prevalence in antenatal women in Pondicherry to be 4 percent.

The scale-up partners selected in Pondicherry were an NGO, the Society for Development Research and Training (SFDRT), and a Catholic order of nuns, the Sisters of St. Joseph who operate Cluny Hospital and a hospice for PLHA called Shanthi Bhavan. SFDRT is a communitybased NGO, one of the first to conduct pioneering work on HIV/AIDS, starting from awareness and education and then offering counseling, STI diagnosis and treatment, nutritional support for PLHA, home visits, and funeral services. Their target groups are sex workers, truck drivers, slum dwellers, street children, and bar workers. Cluny Hospital is a 200-bed multi-specialty hospital in Pondicherry with total outpatient attendance of about 400 per day. The hospital is known for its maternity care, with an average of 300 deliveries per month. Cluny Hospital conducts HIV tests (ELISA, VDRL, spot test) in their laboratory and has a history of treating PLHA. Shanthi Bhavan is a 10-bed hospice that serves terminally ill PLHA, also run by the Sisters of St. Joseph, which opened in July 1999 and is located about five kilometers outside of Pondicherry.

SFDRT and Cluny Hospital with the Shanthi Bhavan hospice were selected as scale-up partners with the idea that their collective strength could be harnessed to achieve the goal of establishing a continuum of care for PLHA. 


\section{Hgrizons}

\section{Scale-up process}

The scaling-up strategy in Pondicherry attempted to take account of the various strengths of the partners. Since SFDRT at baseline did not have facilities for clinical care, it referred cases to Cluny and to the government hospitals. Cluny lacked the community connection and outreach well established by SFDRT. Therefore, the scale-up strategy promoted by YRG CARE was a collaborative approach, aiming to unite several partners to work toward a continuum of care and support for PLHA, reflected in a formal memorandum of understanding (MoU).

Some components of the MoU failed because the partner organizations were very different in size, had distinct organizational cultures and values, and operated according to well-established individual organizational objectives. It became apparent midway through the scaling-up process that some of the partners felt the MoU had been externally imposed and resented this.

The scaling-up process hinged on the implementation of the MoU, and when this faltered, alternative approaches were absent. In hindsight, the overreliance on a single approach was a weakness that should have been anticipated, with contingency plans in place. Nonetheless, a successful collaboration has ensued, depending on the needs of the NGOs and the community, but without a formally acknowledged MoU.

Despite the problems associated with the MoU, the partner organizations as well as other providers in Pondicherry did participate in several capacity-building activities offered by YRG CARE, and these appear to have been well-received and appreciated. But some capacity-building activities for Cluny Hospital, for example, training on prevention of mother-to-child transmission (PMTCT), has not yet resulted in noticeable changes in practices.

By the end of the project there were improvements in the quality and breadth of some services, in particular counseling provided through SFDRT. The capacity building provided by YRG CARE in counseling and documentation was appreciated and appears to have contributed toward positive changes. Other services were added, at the initiative of SFDRT, such as a Community Care Center and a Childcare Center, yet these had not been part of the YRG CARE scaling-up work plan developed with the partners, and the funding was secured from other sources.

\section{Changes in service provision and utilization}

The average number of people who were provided with follow-up counseling increased from one per month at baseline to eight per month by end of project. SFDRT supported an increase in the use of VCT by building a relationship with JIPMER Hospital to use their testing facilities, rather than establishing their own. SFDRT started providing VCT initially among the communities they were working with, such as truckers and sex workers. After establishing their own Community Care Center, SFDRT has expanded the promotion of services among the general public.

Some services were strengthened as a result of scale up. For example, due to the training sessions organized by YRG CARE, SFDRT gained knowledge on making educational materials, and the 
skills from this were applied toward creating a document about their work in the truck stops. The counseling strategies learned by SFDRT staff were helpful for conducting interventions with its target groups. After attending training in participatory community appraisal, the staff applied these new skills for group work with sex workers and their children, self-help groups, truckers, and so on.

Many of the services offered at baseline were not provided according to NACO or YRG CARE guidelines. SFDRT now has operational definitions of each service. Very limited service statistics from Cluny hospital and Shanthi Bhavan have been provided, confounding attempts at a more comprehensive site-wide analysis.

HIV testing and counseling: Through their prevention programs, SFDRT motivates vulnerable populations to come for testing. However, the volume is low, with approximately one or two clients per month requesting HIV testing. Counseling has become more formalized. The steps involved in the pre- and post-test counseling of HIV patients learned during the counseling training programs are followed. Laboratory tests are done at JIPMER Hospital, the Pondicherry AIDS Control Society (PACS), or Cluny Hospital. A counselor accompanies the patients to the laboratory. Post-test counseling is provided for all people tested, regardless of whether the test result is positive or negative.

Ongoing counseling: The counselor of SFDRT periodically contacts PLHA and gives support counseling. Family counseling continues as family members of any HIV patients are counseled to cope with the situation and also with regard to the care of HIV/AIDS patients. The children of PLHA are also given counseling with the permission of their parents. The counseling with children is a specialized service involving psychological tests, done entirely with the expertise of the SFDRT director, who is a psychologist.

Maternity care: The doctors at Cluny Hospital are now trained in prevention of mother-to-child transmission. Cluny Hospital provides maternity care (deliveries and cesarean sections) to the patients referred by SFDRT. Pregnant PLHA are now referred by SFDRT to Cluny Hospital for prenatal care. The research team has not received any information to suggest, however, that PMTCT services are being implemented.

Outpatient care: Doctors are now trained in HIV management. Outpatient care has been extended to infected, affected, and vulnerable children at SFDRT's Childcare Center. SFDRT reports that the number of clients who received outpatient care increased from 14 in 1999 to 45 in 2001.

Inpatient care: SFDRT either treats patients at its new Community Care Center or refers the patients to JIPMER Hospital, the Government General Hospital, Cluny Hospital, and Shanti Bhavan. One doctor at Cluny Hospital was trained in HIV/AIDS clinical management as part of the scale-up project.

Home care: Paramedic staff, two part-time home care nurses, and a part-time home care doctor have been appointed at SFDRT. Medical care and referrals are provided at the home of the PLHA by paramedic staff, field workers, and nurses. Home care also involves removing stigma within 


\section{Hgrizons}

society and family and preparing them (family, relatives, and community leaders) for care at home. They also impart education on the need for care of children in the community.

Prevention: In a separate area, SFDRT organized a television program on World AIDS Day 2000 with support from Family Health International (FHI), which reached an estimated 10,000 or more of the general public in Pondicherry. Nearly 400 members of key populations were reached through street plays. SFDRT also conducts seminars on STD/HIV/AIDS and sex and sexuality for schools and colleges. As a result of a new project funded by FHI, prevention services have expanded to others involved with brothel-based sex work.

Inpatient services: With funding from NACO, SFDRT opened a ten-bed inpatient center for PLHA called the Community Care Center. PLHA who are admitted receive free treatment, food, and medicine. PLHA are provided with family counseling, treatment, home care, and nutrition counseling and support. At present, only medicine for opportunistic infections and vitamins are given, and antiretroviral therapy is not provided. On average, five PLHA are admitted for inpatient care every month. Depending on their health, patients stay an average of five to ten days. Although the center was not part of the current scale-up project, skills learned from an on-site training at YRG CARE attended by the SFDRT nurse have been put to use at the Community Care Center.

Childcare center: Serving over 200 orphaned and vulnerable children and the community, the center includes a crèche for children under three years of age and assistance to help older children attend school. This is a project for infected and affected children provided as an offshoot of care and support services. Nutritional support, medical treatment, nonformal education, vocational training, and recreational activities are also provided. The center was not part of the current scaleup project work plan and is funded by FHI.

Data on inputs and resources mobilized are not available for this site. 


\section{Financial Analysis}

\section{Financial Analysis of Scaling-up}

To assist partner sites in the scaling-up process, researchers used three mechanisms:

- Training program personnel, local providers, and community NGOs.

- Technical assistance to program staff.

- Seed grants to the partner sites to assist with project implementation.

This brief summary describes these efforts by partner site from the perspective of the funders of the scale-up activities.

\section{Training Program Personnel, Local Providers, and Community NGOs}

This activity was supported by YRG CARE through the Horizons Program, with funding and technical support from the International HIV/AIDS Alliance.

The purpose of these training activities was threefold. The primary focus was to ensure that partner site personnel had the knowledge and expertise to deliver comprehensive and patient-centered care and support services to their clients. Topics for the training included care and treatment, counseling, sex and sexuality, mother-to-child HIV transmission, universal precautions and waste management, and laboratory training. A second purpose was to update the knowledge of local service providers in the community about HIV/AIDS, counseling of clients, and to promote the referral of clients to the partner sites by local providers. A final purpose was to educate the scale-up coordinators based within each of the scale-up partner organizations about the IEC materials and other documentation to support the scale-up process.

The total training support provided by YRG CARE is valued at Rs. 707,010. The investment per site ranged from a low of Rs. 32,264 (Asha Kirana) to Rs. 316,784 (Shelter). The training activities were concentrated in two areas: counseling skills and continuing medical education (CME) for local providers. Combined, these activities account for more than 55 percent of total training investment. 


\begin{tabular}{|c|c|c|c|c|}
\hline Training topic & SFDRT & Asha Kirana & Shadows & Shelter \\
\hline Care \& treatment CME & & 27,014 & 46,071 & 22,714 \\
\hline Counseling skills & 60,333 & & 89,883 & 81,783 \\
\hline Sex \& sexuality & 9,920 & & 9,920 & 9,920 \\
\hline РMTCT & 19,000 & & & \\
\hline $\begin{array}{l}\text { Universal precautions } \\
\& \text { waste management }\end{array}$ & & & 25,750 & 18,000 \\
\hline Laboratory training & & & & 32,000 \\
\hline $\begin{array}{l}\text { CME for local } \\
\text { providers }\end{array}$ & 10,750 & & 57,500 & 98,450 \\
\hline $\begin{array}{l}\text { HIV/AIDS training for } \\
\text { local NGOs }\end{array}$ & & & & 20,000 \\
\hline $\begin{array}{l}\text { Counseling training for } \\
\text { local NGOs }\end{array}$ & & & & 19,500 \\
\hline $\begin{array}{l}\text { IEC materials \& } \\
\text { documentation }\end{array}$ & 14,417 & 5,250 & 14,417 & 14,417 \\
\hline Total & Rs. 114,420 & 32,264 & 243,541 & 316,784 \\
\hline
\end{tabular}

\section{Technical Assistance to Program Staff}

Technical support was provided by YRG CARE to the partner sites to strengthen their financial, administrative, and management procedures. In addition, the Alliance provided advice and support on fundraising, developing a scale-up strategy, and conducting a participatory community assessment. The Alliance also provided technical support on HIV/AIDS treatment and drugs and care and support, which were designed to complement the training discussed above.

The total technical assistance support provided to the sites is valued at Rs. 364,850. The investment per site ranged from Rs. 61,600 (Shadows) to Rs. 116,933 (SFDRT). The majority of these technical support activities (71.8 percent) were funded by the Alliance, with supplemental support through YRG CARE. Almost 30 percent of technical support resources were devoted to the participatory community assessment and building local support. 


\begin{tabular}{|c|c|c|c|c|}
\hline $\begin{array}{l}\text { Technical support } \\
\text { topic \& source }\end{array}$ & SFDRT & Asha Kirana & Shadows & Shelter \\
\hline Finance & 7,533 & 7,533 & 7,533 & \\
\hline Administration & 11,250 & & & 11,250 \\
\hline Management & & 19,600 & & \\
\hline Fundraising & 9,650 & 9,650 & 9,650 & 9,650 \\
\hline $\begin{array}{l}\text { Scale-up strategy } \\
\text { workshop }\end{array}$ & 14,217 & 14,217 & 14,217 & \\
\hline HIV treatment \& drugs & 30,200 & & 30,200 & \\
\hline $\begin{array}{l}\text { Participatory } \\
\text { community } \\
\text { assessment \& building } \\
\text { local support }\end{array}$ & 29,583 & 29,583 & & 46,833 \\
\hline Care \& support & 14,500 & 23,500 & & 14,500 \\
\hline Total & Rs. 116,933 & 96,427 & 61,600 & 82,233 \\
\hline YRG CARE & $24.3 \%$ & $38.1 \%$ & $27.9 \%$ & $25.4 \%$ \\
\hline Alliance & $75.7 \%$ & $61.9 \%$ & $72.1 \%$ & $74.6 \%$ \\
\hline
\end{tabular}

\section{Seed Grants to Partner Sites}

This form of support to partner sides was provided by the Alliance and funded by the MacArthur Foundation. These grants were designed to help defray some of the costs associated with the scaleup activities.

Three categories of expenditures were supported by the seed grants: personnel, office or operating expenses, and program implementation. While program implementation used most of the seed grant funds, the composition of these activities varied significantly from site to site. SFDRT and Shadows focused heavily on the development and delivery of IEC materials and training within the community. On the other hand, Asha Kirana focused mainly on training clinicians, followed by development and distribution of IEC materials. Shelter did not train clinicians, instead focusing primarily on training in the community.

Only Asha Kirana and Shelter reported significant spending on travel. All the partners spent a good portion of the seed grant to support the services of counselor(s) and/or a home care nurse (23.0 to 34.3 percent), while SFDRT is the only partner that used seed grant funds for the provision of services outside the NGO to their clients (ambulance service). 


\begin{tabular}{|c|c|c|c|c|}
\hline Category/detail & SFDRT & Asha Kirana & Shadows & Shelter \\
\hline Personnel & 36,500 & 52,000 & 44,000 & 36,000 \\
\hline \# Counselors & $1 \mathrm{FTE}$ & $1(2 \times 0.5$ FTE $)$ & 1 FTE & $0.5 \mathrm{FTE}$ \\
\hline \# Home care nurses & $1 \mathrm{FTE}$ & 0 & $1 \mathrm{FTE}$ & 0 \\
\hline Office/operating & 0 & 5,000 & 27,356 & 5,160 \\
\hline $\begin{array}{l}\text { Audit fees \& bank } \\
\text { charges }\end{array}$ & & 5,000 & 4,774 & 5,160 \\
\hline Telephone & & & 12,834 & \\
\hline Documentation & & & 9,748 & \\
\hline $\begin{array}{l}\text { Program } \\
\text { implementation }\end{array}$ & 99,284 & 94,600 & 77,988 & 115,209 \\
\hline IEC materials & 51,415 & 25,000 & 30,128 & 7,750 \\
\hline Training of clinicians & 1,750 & 51,000 & 6,865 & 0 \\
\hline $\begin{array}{l}\text { Training in the } \\
\text { community }\end{array}$ & 18,359 & 0 & 39,555 & 77,659 \\
\hline Travel & & 18,600 & 1,440 & 29,800 \\
\hline Ambulance service & 27,760 & & & \\
\hline Total & Rs. 135,784 & 151,600 & 149,344 & 156,369 \\
\hline
\end{tabular}

\section{Summary of Scale-up Support to Partners}

The total support received by scale-up partners ranged from Rs. 287,948 (Asha Kirana) to Rs. 555,387 (Shelter).

Looking across the types of support received, there are important differences by site. The SFDRT program in Pondicherry received one-third support from each of the categories. Asha Kirana in Mysore relied heavily on the seed grant for support (52.6 percent), with an additional 36.1 percent in the form of technical assistance, while Shadows in Chirala and Shelter in Calicut used training as their primary source of support (53.6 percent and 57.0 percent, respectively), followed by the seed grant and technical assistance. As a result these two partners received the majority of their support from the Horizons program through YRG CARE, while SFDRT and Asha Kirana received the majority of their support from the Alliance. The "correct" mix of support or use of seed grant funds cannot be specified, since all the organizations begin with a different mix of skills, local resources, and history.

What is interesting from this analysis is how different the approaches can be although the underlying objective was the same for all the partner sites. It will also be interesting to see how 
these organizations build upon these initial activities and how they continue to evolve toward the goal of providing integrated care and support services.

\begin{tabular}{|c|c|c|c|c|}
\hline $\begin{array}{l}\text { Form of support \& } \\
\text { source }\end{array}$ & SFDRT & Asha Kirana & Shadows & Shelter \\
\hline Training & 114,420 & 32,264 & 243,541 & 316,784 \\
\hline Technical assistance & 116,933 & 104,083 & 61,600 & 82,233 \\
\hline Seed grant & 135,784 & 151,600 & 149,344 & 156,369 \\
\hline Total & Rs. 367,187 & Rs. $\quad 287,948$ & 454,485 & 555,387 \\
\hline YRG CARE & $38.9 \%$ & $24.0 \%$ & $57.4 \%$ & $60.8 \%$ \\
\hline Alliance & $61.1 \%$ & $76.0 \%$ & $42.6 \%$ & $39.2 \%$ \\
\hline
\end{tabular}




\section{Key Findings Across Sites}

\section{Selection of appropriate partners with shared vision and commitment is essential.}

The scale-up strategy relied on trust and the mutual sharing of experiences and expertise among the scale-up partners and YRG CARE. For this reason, it was very important that the partners had a shared sense of vision of how to strengthen and expand care and support services. Early in the process, one of the selected partners opted to drop out of the initiative because it did not feel it would benefit from participation, and YRG CARE replaced it with another scale-up partner. A common understanding of objectives and how to get there was indispensable in keeping the capacity-building program on track and communication among all the project stakeholders frank and constructive.

At an end-of-project workshop, all participants agreed that selecting like-minded and compatible partners with shared objectives is very important.

\section{Building skills in the provision of care and support works best when careful attention is paid to provider needs and the capacity-building program is flexible.}

The research identified the importance of starting with a solid assessment of care and support needs among service providers, working closely with them to identify a training program to fill gaps and respond to priority needs and interests. There was a strong preference by the scale-up partners for onsite training wherever possible to ground the training in day-to-day realities, and to enable more local staff and volunteers to participate.

Capacity building should be flexible and accommodate mid-term corrections if necessary. Finding ways to strengthen community participation and have this perspective count is very important. When possible, capacity-building efforts should be extended to include government and other service providers as a way of improving the skills of other providers and strengthening networking and collaboration.

The study identified attitudes and skills particularly difficult to develop within the timeframe of the project, including changing the attitude of providers and the community, participatory communication, advocacy, consistent observance of universal precautions, documentation, resource mobilization, and networking among NGOs and with government. Hands-on training opportunities were considered one especially helpful strategy to make headway in these challenging areas. Appropriate tools and reference materials can be effective in building participatory communication skills. Advocacy skills can be enhanced through visits to organizations that have had success in this area. Consistent observance of universal precautions can be achieved in part by updated practical guidelines and mentoring from more experienced 
providers. Skills in resource mobilization can be improved through training in fund raising and proposal writing.

\section{Ten points of advice on building care and support capacity}

1. Reach a consensus with service providers on priority training topics.

2. Conduct onsite training wherever possible to ground this in the reality of the provider.

3. Establish clear indicators to assess the success of the capacity building.

4. Make a clear distinction between technical support, capacity building, and financial support.

5. Plan for capacity building to be flexible and accommodate mid-term corrections as necessary.

6. Consider prioritizing training on documentation and monitoring.

7. Where appropriate, organize visits between scale-up partners and to other relevant projects.

8. Strengthen community participation and find ways to have the community perspective count in prioritizing capacity-building needs.

9. Link with government and other donor agencies when possible.

10. Ensure that training materials are available in local languages.

These points were elaborated by study participants at the data interpretation workshop held in Kadavu, India, 26-28 September 2002.

Strategies for building the capacity of other government and NGO providers beyond the popular continuing medical education schemes include mentoring and certificate courses that involve multidisciplinary participants including doctors, nurses, and paramedics.

\section{Shared definitions of services with a common understanding of what these consist of are important for planning and monitoring progress.}

The research uncovered inconsistent understandings among the scale-up partners of how particular services are defined. There was an expectation that the Indian National AIDS Control Organization (NACO) guidelines and those from WHO, UNAIDS, and others would have resulted in more consistent definitions in the early stages of the project, but this was not the case.

This lack of consistent service definitions meant that findings from the initial needs assessments were often misleading, giving the impression that various services were offered, when in fact they were not. The process of clarifying service definitions took time, but eventually resulted in a clearer set of expectations and assisted in more productive strategic planning for strengthening and expanding care and support services. A scale-up manager explained how his organization's understanding improved as it was exposed to the capacity-building program: 


\section{Hgrizons}

"We were not aware of the concept of home care at baseline. We now understand home care as seeing and rendering care to the patients at their home. It also means to us that relatives at home can be contacted and taught about care for the PLHA."

\section{A key component of the whole scale-up process was collaboration and networking.}

A central strategy for all the scale-up partners was to strengthen linkages with other care providers and encourage referrals to avoid duplication of services and expand the range of services available. Referrals increased as networking and collaboration intensified through such efforts as continuing medical education. As the volume of referrals grew, so did the availability of care and support services at a given site. A manager at one scale-up partner commented positively about this synergistic link:

"Networking is an important factor. All the local NGOs are referring people to us. We in turn use our network of hospital, labs and clinics for their proper care."

At a different scale-up site, a manager remarked:

"Linking with the CBPS and other organizations with similar interest has given us greater mileage in delivering services and locating patients, and also following up."

A service provider at one of the scale-up sites characterized his organization's relationship with the scale-up partner and others as follows:

"We now function in a complementary manner."

\section{The expansion of care and support resulted in more paid staff and volunteers.}

Increases in the number of paid staff and volunteers were observed among all scale-up partners as more care and support services became available (see Figure 4 for the growth in the number of volunteers for Chirala). Expanding care and support services provides new opportunities for the community to become involved in service provision beyond prevention activities. In resourceconstrained environments, volunteer mobilization is an important strategy for enabling expanded care and support service provision, particularly for home and community care. 
Figure 4 Change in the number of volunteers in Chirala (1999 to 2001)

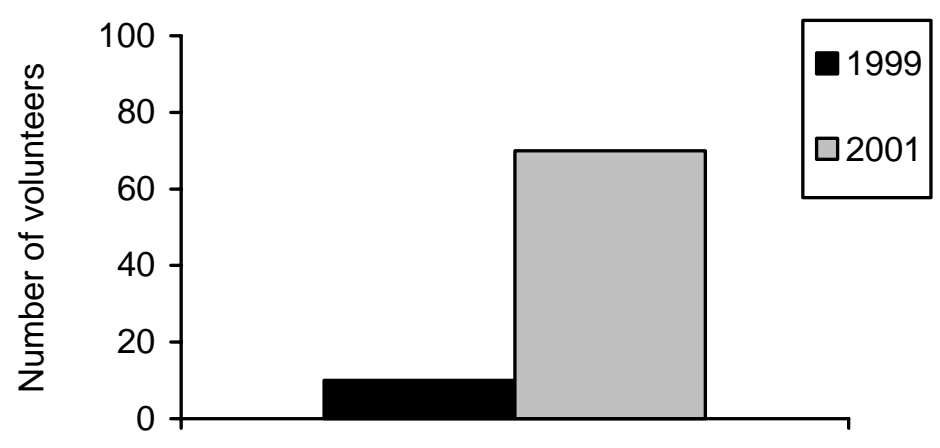

\section{Documentation, monitoring, and reporting were challenges for all the scale-up partners.}

Participants in the study described documentation, monitoring, and reporting as a gradual process of learning and improving, and felt that there had been steady progress throughout the scaling-up period. Nonetheless, documentation skills were an area of weakness widely acknowledged by participants.

"Well we are still not very perfect in documentation, and I have a personal feeling that there is a lot more in that aspect."

Despite the shortcomings of documentation, it was nonetheless recognized as a vital part of scaling up, as mentioned by a counselor at one of the scaling-up sites:

"In this scaling up the documentation is important. At a glance I can make out clearly where we are wrong."

Several reasons were identified as hindering good documentation, including fear of criticism, lack of human resources and skills to monitor and document activities, unclear understanding of the purpose and value of documentation and reporting, and weak organizational commitment for documentation efforts.

\section{Provider attitudes shifted from an emphasis on clinical aspects to valuing patient-centered care and support.}

As is evident in the case studies and from discussions during the end-of-project workshop, all participants reported a shift from an emphasis on the clinical aspects of HIV at the beginning of the scale up, to a much greater emphasis on counseling and other forms of psychosocial support to PLHA, their families, and communities. Study data underscore the importance of counseling and 


\section{Hgrizons}

support within the continuum of care, with clients placing particular value on this. One manager of a scale-up partner commented that:

"The management of HIV/AIDS is not merely a clinical management...the entire system should be linked and followed up. Failing this [care and support] will not be complete."

Part of what has driven this shift in partner thinking has been the feedback of clients who strongly value counseling and other forms of psychosocial support. A client in Mysore commenting on the expanded services there noted:

"Counseling has been the most useful, and it has given a great sense of moral support to me, and given a new meaning to my life."

A client of services in Calicut also expressed high regard for the availability of counseling and clinic staff to talk through problems:

"The doctor will spend the necessary time with me. The counseling is also the same. If I have any doubts the doctor will talk to me freely and clarify."

In Chirala a client explained why counseling was his preferred service:

"Out of the services I liked the counseling. Because there was a time I was thinking that there is no more life for me, at that time I was given the awareness and counseling helped me to look forward to a brighter future."

\section{I ncreased availability of care was associated with higher demand for prevention and care services.}

Expanded voluntary counseling and testing services at the scale-up sites meant that more clients had access to post-test counseling, which focuses on sexual risk reduction and other preventive practices. Through the provision of expanded care and support, partners also established more contact with affected communities, resulting in more targeted prevention services with such key populations as sex workers, men who have sex with men, and PLHA. Contrary to the argument that working on care and support detracts providers from prevention efforts, our study found the opposite to be the case. At every scale-up site, prevention efforts intensified.

Figure 5 indicates the growth in care and support service utilization in Chirala, as well as expanded coverage of prevention activities. 
Figure 5 Changes in service utilization in Chirala

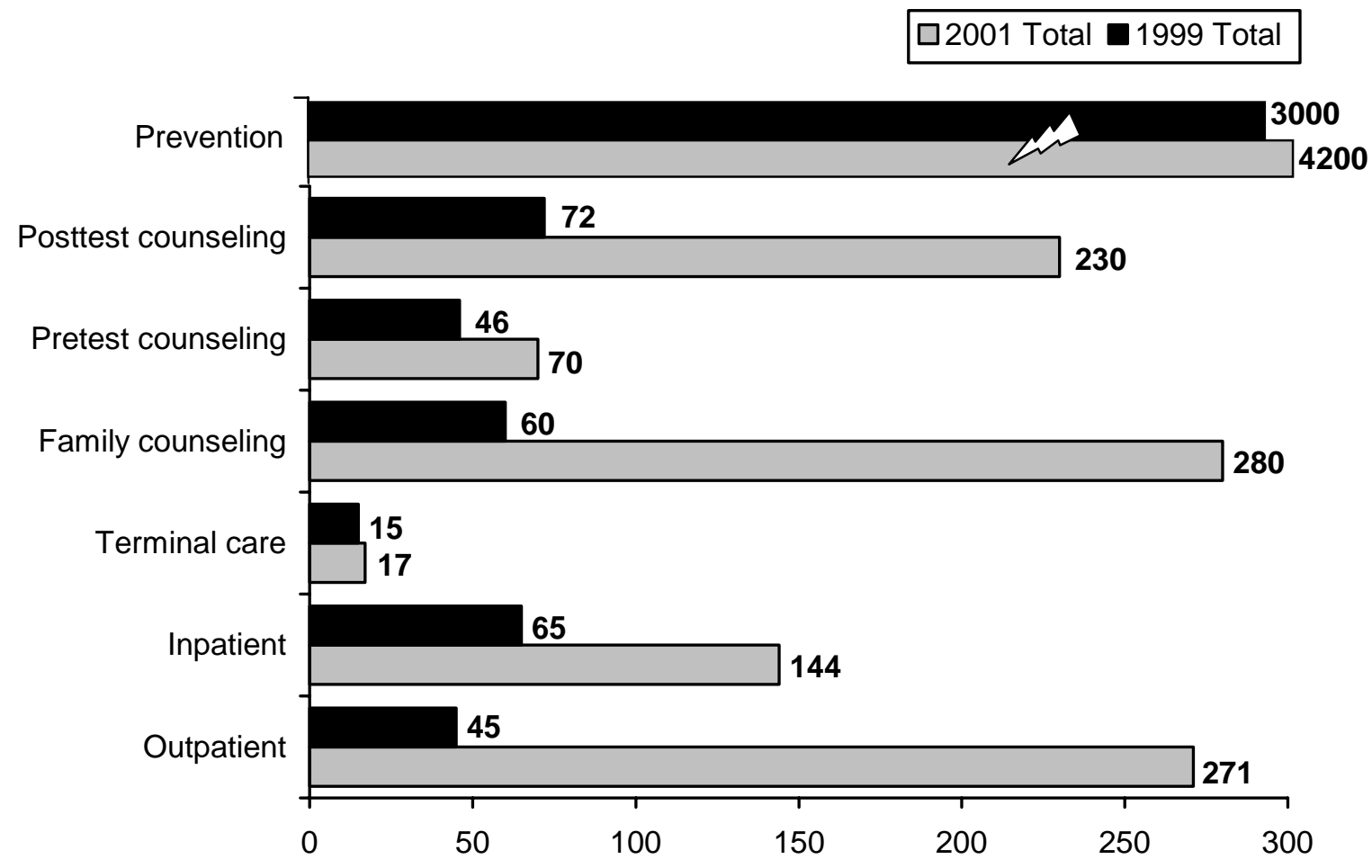

Clients living with HIV/AIDS also expressed appreciation for prevention as well as care and support services, as typified by the following comment:

"They gave me information on AIDS and they gave me confidence as to how the disease is spread and what are the precautions to be taken, and I am feeling very comfortable since that day."

\section{Stigmatization of PLHA and their families was a strong factor requiring attention at all the sites.}

Expanded involvement in care and support has required service providers to address stigma and discrimination experienced by PLHA. Clients described fear of stigma and discrimination as a major barrier to accessing care and support services. One client expressed the fear this way:

"We would like to come, but then we come and somebody will ask us where we are going, then it will be difficult for us to answer." 


\section{H}

Client concerns about stigma and discrimination also appear to be a factor limiting their greater involvement in service provision, as indicated by the following comment:

"I am scared about being recognized as a patient of this center, so I do not want to get involved."

Many providers refused or avoided treating PLHA due to fears that this would affect their reputation and business, with one hospital administrator saying:

"Private health care facilities are hesitant to treat PLHA because they fear a drop in patient inflow."

The scale-up partners intensified educational and awareness-raising activities about the rights of PLHA as well as protests against providers who refused to treat PLHA or who treated them poorly.

The study found that continuing medical education and various training efforts with other providers were useful ways of improving the treatment of PLHA and addressing stigma and discrimination. A counselor at one site commented:

"Whatever the disease, all doctors and hospitals should come forward and give them good treatment. Everybody should look at PLHA like seeing a normal person. Only for that we are conducting a lot of programs. We believe changes will take place due to that."

\section{Much can be accomplished through locally led capacity building.}

This study showed that care and support can be successfully expanded without reliance on large amounts of external funding for outside trainers and seed grants.

The small seed grants provided through YRG CARE to support scale-up efforts did not reach most of the scale-up partners until late in the process, yet despite this, partners had already made significant headway. All partners were adept at mobilizing local cash and in-kind contributions, even through the total value of these contributions remained relatively small. Community mobilization yielded volunteer labor and other valuable forms of support. The director of one scaleup partner described the innovative spirit and creativity in dealing with the lack of funding:

"We plan what needs are and accordingly work for it. For example, when there were problems finding space, the government pitched in and helped us. The Rotary Club participates in health camps and provides medicines and medical care for all kinds of illnesses. Then for nutrition, we have managed to rope in Hotel Mass to provide food for patients...we use our network effectively."

Scale-up partners did acknowledge the high cost of antiretroviral drugs and expressed concern that a majority of their clients could simply not afford them. Clients also expressed concerns about the high cost of ART. 


\section{Discussion and Conclusions}

As is evident in the case studies and from discussions during the data interpretation workshop, participants all reported a shift from an emphasis on the clinical aspects of HIV at the beginning of the scale up, to a much greater emphasis on counseling and other forms of psychosocial support to PLHA, their families, and communities. Study data underscored the importance of counseling and support within the continuum of care, with both male and female clients placing particular value on this.

Concept replication as a strategy for scaling up can result in strengthened and expanded care and support for PLHA and their families. It relies on a strong local organization with the capacity to lead a scale-up process, in this instance YRG CARE, and the availability of like-minded partners who share the same vision, values, and goals.

Stigmatization of PLHA and their families remains severe, poses a key barrier to increased service use, and must be addressed by service providers. Recognition of stigma and discrimination as a key barrier to care and support is a critical first step. Participation in capacity-building activities by the scale-up partners and other providers was identified as one very important strategy for reducing stigma and the poor treatment of PLHA. Many of the scale-up partners reported concerns about greater involvement in HIV/AIDS care and support and the impact it could have on their reputation within the general community, although over time they all saw increases in referrals and the numbers of clients coming for services.

NGO providers find it challenging to document, monitor, and report on their work, and capacity building in this area takes time. Simple and streamlined reporting procedures can help to improve this process. As scale-up partners observed the benefits of more systematic documentation-for example, to promote services and mobilize resources-resistance to investing the necessary time and effort declined.

Greater availability of care and support leads to more demand for prevention services and growth in staff and volunteers. Clients coming for care and support are generally from such key populations as sex workers, men who have sex with men, and migrant laborers. This helped the providers to become more aware of the particular needs and perspectives of these key populations, resulting in more appropriate and targeted prevention services. Expanding care and support services also resulted in an increase in staff and volunteers, a development that was viewed positively by the scaling-up partners.

A lack of external funding need not pose an insurmountable barrier, and much can be done without it. The small seed grants included as part of the scaling up were delayed, yet partners were able to achieve considerable progress in improving and expanding care and support nonetheless.

Intensified collaboration and networking with existing providers, including government clinics and hospitals and other NGOs, was a common strategy employed by all the partners. 


\section{${ }^{H} \boldsymbol{X}^{\text {rizons }}$}

At the end of project workshop, scale-up participants and YRG CARE affirmed their intention to continue collaboration in order to build on the successes of the project, and to bring other new sites into the network in order to improve and expand the continuum of care and support in South India. The group is determined to maintain momentum and to continue offering capacity-building activities through training workshops, exchange visits, and other mechanisms. This determination to extend the collaboration, even though the research project and external technical and financial support from the Alliance has ended, is perhaps one of the strongest indications that concept replication as a strategy for scaling up is sustainable in the longer term. 


\section{References}

DeJong, Jocelyn. 2003. Making an Impact in HIV/AIDS: NGO Experiences of Scaling Up. London: ITDG Publishing.

FOCUS. 1999. Eight ideas to develop and scale up adolescent reproductive health programs. Washington, DC: Pathfinder International

Gilks, C., K. Floyd, D. Haran, J. Kemp, B. Squire, and D. Wilkinson. 1998. Sexual health and health care: care and support for people with HIV/AIDS in resource-poor settings. London: Department for International Development (DFID).

Horizons Program and IMPACT/FHI. 2000. Current Issues in HIV Counseling and Testing in South and Southeast Asia. New Delhi.

Ramasundaram, S. et al. 2001. "HIV/AIDS control - Lessons learned from Tamil Nadu." Geneva: Commission on Macroeconomics and Health, WHO.

Solomon, Suniti et al. 2001. The YRG CARE Model: An integrated continuum of prevention, and care and support for people living with HIV/AIDS. Washington DC: Horizons Program. http://www.popcouncil.org/pdfs/horizons/yrgcrbsmdl.pdf

UNAIDS. 1998. Report on the Global HIV/AIDS Epidemic. Geneva, www.who.int/emchiv/global_report/rep_html/report3.html 
Appendix

\section{Capacity building program and continuing medical education courses, 2000-2001}

\section{Capacity building program}

\begin{tabular}{|c|c|c|c|c|c|}
\hline Date & Topic & Duration & Location & Participants & Organizers \\
\hline $\begin{array}{l}\text { Jan. } \\
' 00\end{array}$ & Laboratory training & 5 days & Chennai & $\begin{array}{l}\text { Calicut Lab } \\
\text { technician }\end{array}$ & $\begin{array}{l}\text { YRG CARE } \\
\text { and WHO }\end{array}$ \\
\hline $\begin{array}{l}\text { Feb. } \\
{ }^{\prime} 00\end{array}$ & $\begin{array}{l}\text { "Non-profit good } \\
\text { practices" - Project } \\
\text { management and } \\
\text { proposal writing }\end{array}$ & 2 days & Chennai & $\begin{array}{l}\text { SUC from } \\
\text { Pondicherry }\end{array}$ & YRG CARE \\
\hline $\begin{array}{l}\text { May } \\
\circ 00\end{array}$ & $\begin{array}{l}\text { Proposal writing and } \\
\text { fund raising }\end{array}$ & 2 days & Mysore & $\begin{array}{l}\text { SUC from } \\
\text { Pondicherry }\end{array}$ & YRG CARE \\
\hline $\begin{array}{l}\text { Aug } \\
{ }^{\prime} 00\end{array}$ & Fund raising & 2 days & Chennai- & $\begin{array}{l}\text { SUC from } \\
\text { Pondicherry }\end{array}$ & $\begin{array}{l}\text { YRG CARE } \\
\text { (external) }\end{array}$ \\
\hline $\begin{array}{l}\text { Aug. } \\
{ }^{\circ} 00\end{array}$ & $\begin{array}{l}\text { Finance management } \\
\text { and accountancy }\end{array}$ & 1 day & Chennai & $\begin{array}{l}\text { Project manager, } \\
\text { administrator } \\
\text { from } \\
\text { Pondicherry } \\
\end{array}$ & YRG CARE \\
\hline $\begin{array}{l}\text { Dec. } \\
{ }^{\prime} 00\end{array}$ & $\begin{array}{l}\text { Training on IEC } \\
\text { materials and } \\
\text { documentation }\end{array}$ & 4 days & Sholinganallur & $\begin{array}{l}\text { SUC from } \\
\text { Pondicherry }\end{array}$ & $\begin{array}{l}\text { YRG CARE } \\
\text { and Ford } \\
\text { Foundation }\end{array}$ \\
\hline $\begin{array}{l}\text { Feb. } \\
{ }^{\prime} 01\end{array}$ & $\begin{array}{l}\text { HIV-related treatment } \\
\text { and drugs }\end{array}$ & 5 days & Delhi & $\begin{array}{l}\text { Director and } \\
\text { SUC from } \\
\text { Pondicherry }\end{array}$ & Alliance \\
\hline $\begin{array}{l}\text { Mar. } \\
' 01\end{array}$ & Counseling training & 4 days & Chennai & $\begin{array}{l}\text { Counselors from } \\
\text { Calicut and } \\
\text { Chirala }\end{array}$ & YRG \\
\hline $\begin{array}{l}\text { May } \\
\text { '01 }\end{array}$ & $\begin{array}{l}\text { Biomedical Workshop } \\
\text { on ethics in research }\end{array}$ & 1 day & Chennai & $\begin{array}{l}\text { Director and } \\
\text { SUC from } \\
\text { Chirala }\end{array}$ & YRG and JHU \\
\hline $\begin{array}{l}\text { May } \\
\text { '01 }\end{array}$ & Counseling training & 3 days & Chennai & $\begin{array}{l}\text { Counselors and } \\
\text { Psychiatrist from } \\
\text { Calicut, and } \\
\text { Chirala }\end{array}$ & $\begin{array}{l}\text { YRG and } \\
\text { Rainy Hospital }\end{array}$ \\
\hline $\begin{array}{l}\text { June } \\
{ }^{\prime} 01\end{array}$ & $\begin{array}{l}\text { Training on sex and } \\
\text { sexuality }\end{array}$ & 2 days & Chennai & $\begin{array}{l}\text { Director and } \\
\text { SUC from } \\
\text { Calicut, and } \\
\text { Chirala } \\
\end{array}$ & YRG \\
\hline $\begin{array}{l}\text { June } \\
{ }^{\prime} 01 \\
\end{array}$ & $\begin{array}{l}\text { Counseling training for } \\
\text { nurses and counselors }\end{array}$ & 3 days & Chennai & Calicut SUC & $\begin{array}{l}\text { YRG and } \\
\text { WAF }\end{array}$ \\
\hline $\begin{array}{l}\text { July } \\
\text { '01 }\end{array}$ & $\begin{array}{l}\text { Participatory } \\
\text { Community } \\
\text { Assessment }\end{array}$ & 5 days & Chennai & $\begin{array}{l}\text { SUC and } \\
\text { counselor from } \\
\text { Pondicherry }\end{array}$ & $\begin{array}{l}\text { Alliance and } \\
\text { YRG CARE }\end{array}$ \\
\hline
\end{tabular}




\begin{tabular}{|c|c|c|c|c|c|}
\hline Date & Topic & Duration & Location & Participants & Organizers \\
\hline $\begin{array}{l}\text { Aug. } \\
\text { '01 }\end{array}$ & $\begin{array}{l}\text { Care and support } \\
\text { workshop }\end{array}$ & 3 days & Kanyakumari & $\begin{array}{l}\text { Director and } \\
\text { project manager } \\
\text { from } \\
\text { Pondicherry }\end{array}$ & $\begin{array}{l}\text { YRG CARE } \\
\text { and Ford } \\
\text { Foundation }\end{array}$ \\
\hline $\begin{array}{l}\text { Aug. } \\
{ }^{0} 01\end{array}$ & $\begin{array}{l}\text { Counseling training for } \\
\text { nurses and counselors }\end{array}$ & 3 days & Chirala & $\begin{array}{l}\text { Nurses and } \\
\text { counselors from } \\
\text { Chirala }\end{array}$ & $\begin{array}{l}\text { YRG and } \\
\text { World AIDS } \\
\text { Foundation } \\
\text { (WAF) } \\
\end{array}$ \\
\hline $\begin{array}{l}\text { Aug. } \\
{ }^{\prime} 01\end{array}$ & $\begin{array}{l}\text { Universal precautions } \\
\text { and waste management } \\
\text { training for class iv } \\
\text { workers }\end{array}$ & 1 day & Chirala & $\begin{array}{l}\text { Class IV workers } \\
\text { from Chirala }\end{array}$ & $\begin{array}{l}\text { YRG and } \\
\text { WAF }\end{array}$ \\
\hline $\begin{array}{l}\text { Sept. } \\
\text { '01 }\end{array}$ & $\begin{array}{l}\text { Universal precautions } \\
\text { and waste management } \\
\text { training for Class IV } \\
\text { workers }\end{array}$ & 2 days & Calicut & $\begin{array}{l}\text { Class IV workers } \\
\text { from Calicut }\end{array}$ & $\begin{array}{l}\text { YRG and } \\
\text { WAF }\end{array}$ \\
\hline $\begin{array}{l}\text { Sept. } \\
01\end{array}$ & $\begin{array}{l}\text { Communication skills, } \\
\text { program delivery } \\
\text { methodology and } \\
\text { participatory tools and } \\
\text { activities }\end{array}$ & 3 days & Chennai & $\begin{array}{l}\text { Administrator } \\
\text { and project } \\
\text { manager from } \\
\text { Pondicherry }\end{array}$ & $\begin{array}{l}\text { YRG CARE } \\
\text { and Ford } \\
\text { Foundation }\end{array}$ \\
\hline $\begin{array}{l}\text { Oct. } \\
{ }^{\prime} 01\end{array}$ & $\begin{array}{l}\text { Training on human } \\
\text { resource management }\end{array}$ & 1 day & Chennai & $\begin{array}{l}\text { Administrator } \\
\text { and project } \\
\text { manager from } \\
\text { Pondicherry }\end{array}$ & $\begin{array}{l}\text { YRG CARE } \\
\text { and Ford } \\
\text { Foundation }\end{array}$ \\
\hline $\begin{array}{l}\text { Oct. } \\
{ }^{\prime} 01\end{array}$ & Documentation & 1 day & Chennai & $\begin{array}{l}\text { Counselor and } \\
\text { SUC from } \\
\text { Pondicherry }\end{array}$ & $\begin{array}{l}\text { YRG CARE } \\
\text { and Ford } \\
\text { Foundation }\end{array}$ \\
\hline $\begin{array}{l}\text { Nov. } \\
01\end{array}$ & $\begin{array}{l}\text { HIV/AIDS training } \\
\text { workshop for NGOs }\end{array}$ & 2 days & Malappuram & $\begin{array}{l}\text { Nursing students } \\
\text { and counselors } \\
\text { from Calicut }\end{array}$ & $\begin{array}{l}\text { Shelter and } \\
\text { IYA, Calicut }\end{array}$ \\
\hline $\begin{array}{l}\text { Nov. } \\
01\end{array}$ & $\begin{array}{l}\text { Counseling workshop } \\
\text { for NGOs }\end{array}$ & 1 day & Calicut & $\begin{array}{l}\text { NGOs from } \\
\text { Calicut }\end{array}$ & $\begin{array}{l}\text { Shelter, } \\
\text { Calicut }\end{array}$ \\
\hline
\end{tabular}


CME courses in basic HIV/ AI DS clinical management

\begin{tabular}{|l|l|l|l|l|}
\hline Date & Participants & Duration & Location & Organizers \\
\hline May '00 & $\begin{array}{l}\text { Physicians from } \\
\text { Mysore }\end{array}$ & 4 hours & Mysore & $\begin{array}{l}\text { Asha Kirana } \\
\text { supported by YRG } \\
\text { CARE }\end{array}$ \\
\hline May '00 & $\begin{array}{l}\text { Nurses and } \\
\text { paramedics from } \\
\text { Mysore }\end{array}$ & 2 days & Mysore & $\begin{array}{l}\text { Asha Kirana } \\
\text { supported by YRG } \\
\text { CARE }\end{array}$ \\
\hline July '00 & $\begin{array}{l}\text { Physicians from } \\
\text { Chirala }\end{array}$ & 2 hours & Chirala & $\begin{array}{l}\text { SHADOWS } \\
\text { supported by YRG } \\
\text { CARE }\end{array}$ \\
\hline July '00 & $\begin{array}{l}\text { Nurses and } \\
\text { paramedics from } \\
\text { Chirala }\end{array}$ & 2 hours & Chirala & $\begin{array}{l}\text { SHADOWS } \\
\text { supported by YRG } \\
\text { CARE }\end{array}$ \\
\hline Sept. '00 & $\begin{array}{l}\text { Nurses and } \\
\text { paramedics from } \\
\text { Calicut }\end{array}$ & 2 hours & Calicut & $\begin{array}{l}\text { Shelter supported by } \\
\text { YRG CARE }\end{array}$ \\
\hline Sept. '00 & $\begin{array}{l}\text { Physicians from } \\
\text { Calicut }\end{array}$ & 2 hours & Calicut & $\begin{array}{l}\text { Shelter supported by } \\
\text { YRG CARE }\end{array}$ \\
\hline Dec. '00 & $\begin{array}{l}\text { Physicians from } \\
\text { Calicut and } \\
\text { Chirala }\end{array}$ & 5 days & Chennai & $\begin{array}{l}\text { YRG CARE and } \\
\text { WAF }\end{array}$ \\
\hline May '01 & Physicians & 2 hours & Thiruvalla & Shelter \\
\hline May '01 & Physicians & 2 hours & Kozhencherry & Shelter \\
\hline June '01 & $\begin{array}{l}\text { Physicians and } \\
\text { nurses from } \\
\text { Cluny Hospital, } \\
\text { JIPMER, Govt. } \\
\text { hospital }\end{array}$ & 1 day & Pondicherry & Cluny Hospital \\
\hline Physicians & 2 hours & Chilkulirpet & SHADOWS \\
\hline
\end{tabular}




\section{Hgrizons $\lambda$}

Horizons is a global operations research program designed to:

- Identify and test potential strategies to improve HIV/AIDS prevention, care, and support programs and service delivery.

- Disseminate best practices and utilize findings with a view toward scaling up successful interventions.

\section{(2) Population Council}

Horizons is implemented by the Population Council in collaboration with

- International Center for Research on Women (ICRW)

- International HIV/AIDS Alliance

- Program for Appropriate Technology in Health (PATH)

- Tulane University

- Family Health International (FHI)

- Johns Hopkins University

For more information, please contact:

Horizons Program, Communications Unit 4301 Connecticut Avenue, NW Suite 280 Washington, DC 20008 USA

Tel: 202-237-9400

Fax: 202-237-8410

Email: horizons@pcdc.org www.popcouncil.org/horizons 